\title{
Medullary thyroid carcinoma beyond surgery: advances, challenges, and perspectives
}

\author{
Lucieli Ceolin, Marta Amaro da Silveira Duval, Antônio Felippe Benini, Carla Vaz Ferreira and Ana Luiza Maia
}

Thyroid Unit, Endocrine Division, Hospital de Clínicas de Porto Alegre, Universidade Federal do Rio Grande do Sul, Porto Alegre, Rio Grande do Sul, Brasi Correspondence should be addressed to A L Maia: almaia@ufrgs.br

\begin{abstract}
Medullary thyroid carcinoma (MTC) is a rare type of tumor that originates from thyroid $C$ cells and accounts for $2-4 \%$ of all malignant thyroid neoplasms. MTC may occur sporadically or be inherited, as part of the MEN 2 syndrome. Germline mutations of the RET (REarranged during Transfection) proto-oncogene cause hereditary cancer, whereas somatic RET mutations and, less frequently, RAS mutations have been described in sporadic MTC samples. Since early surgery with complete resection of tumor mostly determines the likelihood of attaining cure for MTC, the broader use of RET genetic screening has dramatically changed the prognostic of gene carriers in hereditary MTC. Nevertheless, despite recent advances, the management of advanced, progressive MTC remains challenging. The multikinase inhibitors (MKI), vandetanib and cabozantinib, were approved for the treatment of progressive or symptomatic MTC, and several other compounds have exhibited variable efficacy. Although these drugs have been shown to improve progression-free survival, no MKI has been shown to increase the overall survival. As these drugs are nonselective, significant off-target toxicities may occur, limiting achievement of the required TK-specific inhibition. Recently, next-generation small-molecule TKI has been developed. These TKI are specifically designed for highly potent and selective targeting of oncogenic RET alterations, making them promising drugs for the treatment of advanced MTC. Here, we summarize the current understanding of the intracellular signaling pathways involved in MTC pathogenesis as well as the therapeutic approaches and challenges for the management of advanced MTC, focusing on targeted molecular therapies.
\end{abstract}

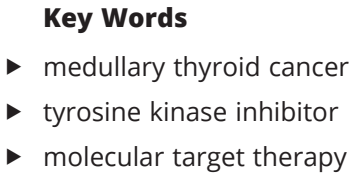

Endocrine-Related Cancer (2019) 26, R499-R518

\section{Introduction}

Medullary thyroid carcinoma (MTC) is a malignant tumor originating in parafollicular or $\mathrm{C}$ cells of the thyroid. The main secretory product of MTC is calcitonin, a specific and highly sensitive biomarker that is produced by normal and neoplastic $\mathrm{C}$ cells. Neoplastic $\mathrm{C}$ cells also produce the carcinoembryonic antigen (CEA). These molecules are widely used markers for the diagnosis, prognosis, and follow-up of MTC patients.
The overall frequency of MTC is not well established, but it has recently shown an increase from 0.14 to 0.21 per 100,000 population between 1983 and 2012 in the USA (Randle et al. 2017). The prevalence is $\sim 2 \%$ of all thyroid malignancies, $0.4-1.4 \%$ of all thyroid nodules, and it is detected in $\sim 0.14 \%$ thyroids of subjects submitted to autopsy (Valle \& Kloos 2011, Tuttle et al. 2014, Lim et al. 2017). The clinical presentation is mainly in the fourth
C) 2019 Society for Endocrinology Published by Bioscientifica Ltd. Printed in Great Britain 
and fifth decades of life with a small, but statistically significant, increase in diagnosis at a mean age from 50 to 54 years (Randle et al. 2017). MTC accounts for $13.4 \%$ of the total deaths attributable to thyroid cancer (Modigliani et al. 1998).

Approximately $35 \%$ of patients with MTC who present with a palpable thyroid nodule have cervical metastases, and $\sim 13 \%$ have distant metastases (Kebebew et al. 2005, Roman et al. 2006). The reported 10-year disease-specific mortality rate for MTC varies from 13.5 to 38\% (Girelli et al. 1998, Kuo et al. 2018). The tumor stage at the time of diagnosis and the possibility of a complete surgical resection mostly determine the likelihood of attaining a cure for MTC. The classical main prognostic factors are age, tumor size, local and distant metastases, somatic M918T mutations, calcitonin, and CEA doubling times (Meijer et al. 2010).

MTC presents as sporadic (75-80\%) or inherited tumors (20-25\%). Hereditary MTC appears as part of the MEN 2 syndrome. MTC is extremely rare in children, making the probability of a hereditary form very high. Germline mutations of the RET (REarranged during Transfection) proto-oncogene cause hereditary cancer, whereas somatic RET mutations are frequently present in sporadic disease (Eng et al. 1995, Mulligan 2018). RET encodes a transmembrane receptor, and point-activating RET mutations promote continuous phosphorylation of a distinct set of tyrosine residues, triggering intracellular signaling pathways responsible for cell survival, differentiation, and proliferation (Fig. 1).

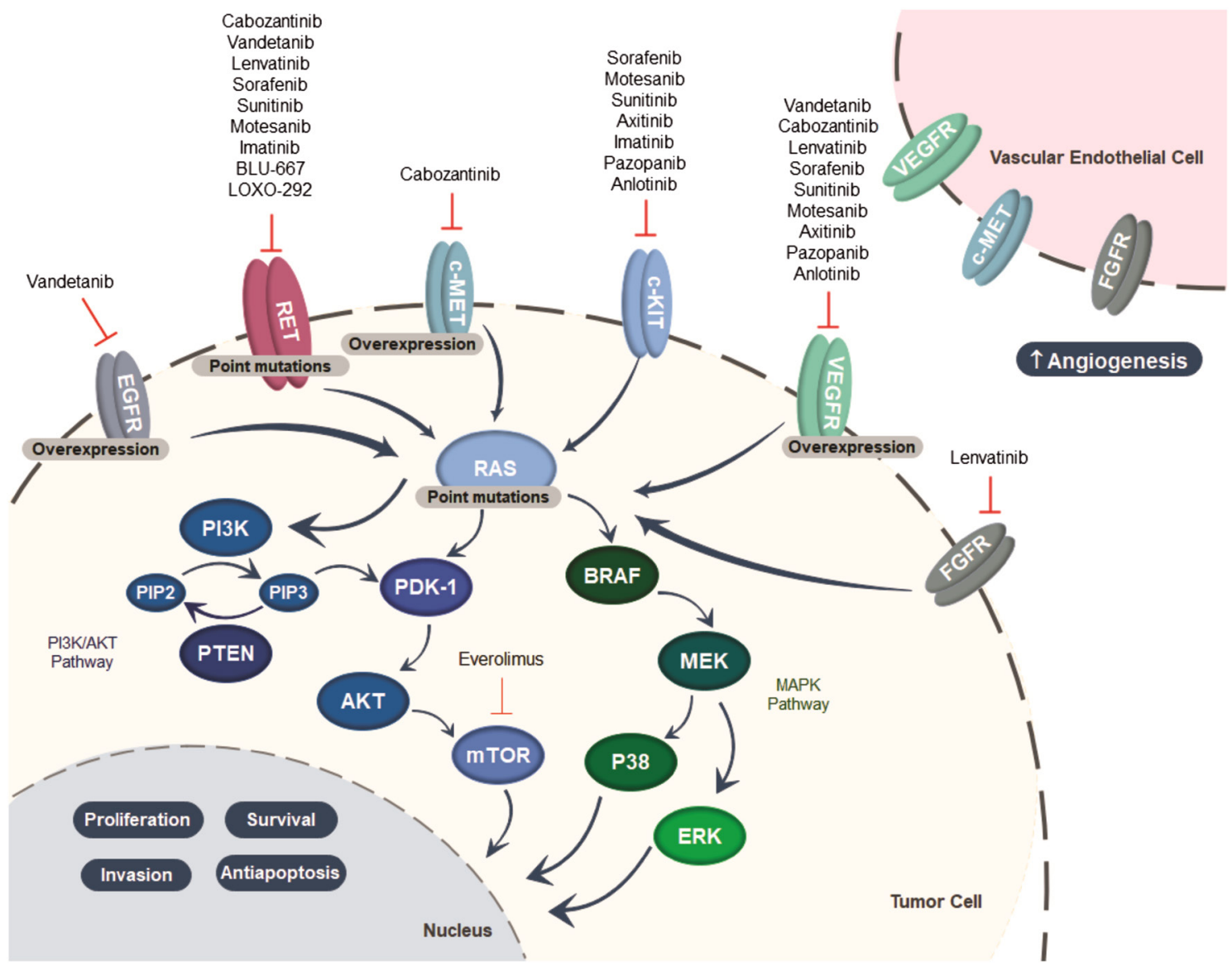

Figure 1

Illustration of the activated pathways and genetic aberrations involved in medullary thyroid cancer, as well as the molecular targeted-related compounds. AKT, v-akt murine thymoma viral oncogene homolog; BRAF, serine/threonine-protein kinase B-Raf; c-Kit, tyrosine-protein kinase Kit; c-MET, hepatocyte growth factor; EGFR, epidermal growth factor receptor; ERK, extracellular signal-regulated kinase; FGFR, fibroblast growth factor receptor; MEK, mitogen-activated protein kinase kinase; mTOR, mammalian target of rapamycin; P38, mitogen-activated protein kinase; PDK-1, pyruvate dehydrogenase kinase isozyme 1; PI3K, phosphatidylinositol-3 kinase; PIP2, phosphatidylinositol (4,5) biphosphate; PIP3, phosphatidylinositol 3,4,5-triphosphate; PTEN, phosphatase and tensin homolog; RAS, rat sarcoma viral oncogene homolog; RET, rearranged during transfection; VEGFR, vascular endothelial growth factor receptor. 


\section{Clinical presentation and genotype-related phenotypes}

Hereditary MTC is usually associated with C-cell hyperplasia, multicentric, and bilateral (Schmid 2015), while the diagnosis of sporadic forms tends to be late, generally in the fifth or sixth decade of life (Heshmati et al. 1997). Lymph node metastases occur in at least 35\% of MTC patients at diagnosis, while distant metastases occur in approximately $20 \%$ of cases. A minority of patients with MTC present systemic manifestations that include diarrhea, flushing, or painful bone metastases (Kebebew et al. 2000, Elisei et al. 2008, Hannah-Shmouni et al. 2016).

Hereditary MTC is inherited as an autosomal dominant syndrome that involves other endocrine neoplasias, with a variable degree of expressivity and an age-related penetrance, named multiple endocrine neoplasia type 2 (MEN 2). Interestingly, MEN 2 syndrome is classically defined by the occurrence of multicentric tumor formation in organs in which the RET proto-oncogene is expressed. This idea emerged because thyroid $C$ cells have long been considered to be derived from neural crest cells. However, recent lineage-tracing experiments in mouse embryos have demonstrated that thyroid C-cell precursors are derived from anterior endoderm, specifically from the pharyngeal pouches from which the ultimobranchial bodies develop (Johansson et al. 2015). These surprising results may disprove the current concept of a neural crest origin of thyroid $\mathrm{C}$ cells and would have implications for understanding coincidental tumorigenesis of MTC, pheochromocytoma (PHEO) and hyperparathyroidism (HPT), revealing new paths for investigation of the involved molecular mechanisms (Nilsson \& Williams 2016).

The MEN 2 syndrome is classified according to the involved organs as multiple endocrine neoplasia type 2A (MEN 2A) and multiple endocrine neoplasia type 2B (MEN 2B) (Pelizzo et al. 2007, Wells et al. 2015). MEN 2A constitutes approximately $70-80 \%$ of all MEN 2 cases and classically includes four subtypes: classical MEN 2A, MEN 2A associated with cutaneous lichen amyloidosis (CLA), MEN 2A and Hirschsprung's disease (HD), and familial medullary thyroid carcinoma (FMTC). Classical MEN 2A is characterized by the presence of MTC (95\%), PHEO (30-50\%) and HPT (10-20\%). MEN 2A with CLA, a pruriginous lesion in the scapular region characterized by amyloid deposition, and MEN 2A with HD, caused by the absence of autonomic ganglia in the terminal hindgut that results in colonic dilatation, obstipation, and constipation are rare variants of the disease
(Gagel et al. 1989, Decker et al. 1998). Previously, considered a freestanding syndrome, FMTC, characterized by the presence of an inheritable MTC with no association with other endocrine neoplasia, is now regarded as a variant of the MEN 2A spectrum, in which the clinical presentation of MTC occurs later, and the prognosis is more favorable in comparison to the other forms of MTC. The reclassification into MEN 2A resulted from the concern that premature categorization of a family with FMTC could lead to a failure to identify a PHEO.

The clinical course of MTC in patients with MEN 2A is variable, and the disease progression is associated with codon-specific mutations in the RET proto-oncogene (Eng et al. 1996a, Machens et al. 2003). Approximately 98\% of MEN 2A is associated with RET mutations in the cysteinerich extracellular domain, particularly in exons 10 and 11 , codons $609,611,618,620$, and 634 , which is responsible for at least $85 \%$ of MEN 2A cases and correlated with the presence of PHEO, HPT, and CLA (Eng et al. 1996b, Raue \& Frank-Raue 2009, Scapineli et al. 2016, Maciel et al. 2019). Amino acid change in the intracellular domain of RET in exon 13 (codons 768,790 and 791), exon 14 (codons 804 and 844) and exon 15 (codon 891) are less frequent. Mutations in exon 8 (codon 533) is rare, but they have been described in a large Brazilian family (Da Silva et al. 2003) and are most prevalent in familial cases in the Greek population (Sarika et al. 2015, Maciel et al. 2019). In 2-5\% of cases of apparently hereditary MTC, no RET mutations are found (Leboulleux et al. 2004). Of note, whole exome sequencing has recently identified a germline MET mutation in two siblings with hereditary WT RET MTC (Sponziello et al. 2018).

A distinct MTC biological behavior, characterized by reduced aggressiveness and an older mean age at diagnosis, has been described for MEN 2A associated with mutations in noncysteine codons comparatively to mutations in cysteine codons (Raue \& Frank-Raue 2009), and mutations in codon 611 tend to give rise to slow tumor progression than mutations in codons 618 and 620 (Machens et al. 2018). On the other hand, more advanced stage and increasing risk of metastases correlated with mutations in codon position $(609 \rightarrow 620)$ near the juxtamembrane domain (Frank-Raue et al. 2011). Interestingly, specific nucleotide and amino acid exchanges seem to have an impact on tumor behavior and aggressiveness in patients harboring codon 634 mutations (Punales et al. 2003). Of interest, a case of aggressive sporadic MTC with a somatic RET C634R mutation and germline synonymous C630C mutation was reported. Expression analysis has shown increased levels of RET transcript in C630C/C634R 
compared with that observed in 7 MTCs harboring only C634 mutations, suggesting that synonymous mutations can contribute to cancer progression (Pecce et al. 2018).

The MEN 2B accounts for approximately 5\% of the cases of MEN 2 and is characterized by a single phenotype, which includes diffuse ganglioneuromatosis of the tongue, lips, eyes, and gastrointestinal tract, Marfanoid habitus, and alacrimia. MEN 2B patients present with MTC (90\%), PHEO (45\%), ganglioneuromatosis (100\%), and Marfanoid habitus (65\%). MTC in the setting of MEN 2B develops earlier and has a more aggressive course compared with MTC in other MEN 2 subtypes (Brandi et al. 2001, Makri et al. 2018). A specific mutation in $R E T$ exon 16, M918T, is almost invariably associated with MEN 2B and usually presents MTC development a few years after birth. Other mutations rarely associated with MEN 2B have been reported at codon 883 of exon 15; however, MTC in A883F carriers seems to present a more indolent course in comparison to M918T carriers (Mathiesen et al. 2017). Double RET mutations involving codons $804 / 806,804 / 778$ or $804 / 904$ have also been described (Kasprzak et al. 2001, Menko et al. 2002, Kihara et al. 2014). A recent large, multicenter study has shown that over $80 \%$ of the cases of MEN $2 \mathrm{~B}$ are de novo RET mutations, implying that the majority of children will be diagnosed after the recommended age of thyroidectomy. These observations highlight the importance to educate pediatricians and other health care providers to recognize the early nonendocrine manifestations of the disease (Castinetti et al. 2019).

\section{Sporadic MTC}

The molecular mechanisms involved in sporadic MTC have not yet been clarified. Approximately $23-66 \%$ of sporadic MTC presents the somatic RET M918T mutation. Also, mutations in codons $618,603,634,768,804$, and 883 and partial deletion of the RET gene have been described in a few tumors (Dvorakova et al. 2008, Elisei et al. 2008, Romei et al. 2016). However, the mutations are not uniform throughout the tumor, suggesting that sporadic MTC might have a polyclonal origin or that these mutations are secondary events of MTC tumorigenesis (Eng et al. 1996b, Romei et al. 2018).

In addition to gain-of-function RET mutations, several RET variants have been associated with an increased risk of development or progression of MTC (Ceolin et al. 2012a,b). Nevertheless, the mechanism by which these variants modulate MTC pathogenesis remains unclear. The exchange of bases in the DNA molecule may create an alternative splicing site, leading to the synthesis of a truncated protein, erroneous ligand binding, micro-RNA binding, or a change in mRNA structure and stability as well as in the number of copies (Borrego et al. 1999). It is also possible that this neutral variant is in linkage disequilibrium (LD) with an as yet unknown functional variant. Indeed, it has been shown that the S836S polymorphism is in LD with the intronic IVS1-126G $>T$ variant found to be overrepresented in a cohort of sporadic MTC patients (Fernandez et al. 2006). LD between RET S836S and 3'untranslated region (UTR) variants has also been demonstrated. Of note, the RET mRNA sequence carrying the S836S/3'UTR haplotype presents higher structural and thermodynamic stability, suggesting a functional involvement of the $3^{\prime} \mathrm{UTR}$ variant allele in the posttranscriptional control of RET (Ceolin et al. 2016). Sporadic MTC patients present higher DNA methylation levels compared to those with the inherited form or control individuals, which might suggest an epigenetic contribution to MTC tumorigenesis (Ceolin et al. 2018). Moreover, epigenetic-related gene profiling shows significant increases of histone methyltransferases genes, which are involved in transcriptional regulation of gene expression, in patients with aggressive MTC (Sponziello et al. 2014).

\section{Diagnosis and prognostic markers}

The clinical presentation of MTC traditionally consists of a palpable thyroid nodule, which may be solitary or appears in the context of a multinodular goiter. Subsequently, the diagnosis is performed through the typical diagnostic work-up of thyroid nodules (Haugen et al. 2016). The routine use of serum calcitonin in the evaluation of thyroid nodules is not a consensus. The European Thyroid Society recommends it, but not the Brazilian Society of Endocrinology (Schlumberger et al. 2012, Maia et al. 2014), while the current guidelines of the American Thyroid Association state that there is no evidence to recommend for or against calcitonin measurements in nodule evaluations (Haugen et al. 2016). There was an agreement that, in certain situations, such as patients considered for less than total thyroidectomy or with suspicious cytology not consistent with papillary thyroid cancer, serum calcitonin measurement should be considered. In these situations, serum calcitonin presents a positive predictive value of $100 \%$ if $>100 \mathrm{pg} / \mathrm{mL}$ and $5 \%$ if between 10 and $100 \mathrm{pg} / \mathrm{mL}$ (Wells et al. 2015, Tormey et al. 2017, Turk et al. 2017). 
Besides, calcitonin measurement in the fine-needle aspiration (FNA) washout might be an additional tool when FNA biopsy findings are inconclusive or undetermined (Trimboli et al. 2014). Nevertheless, one should keep in mind that false-positive results have been reported in selected cases (Massaro et al. 2009, Trimboli et al. 2012).

Calcitonin is the most important MTC marker, as it is useful for diagnosis, surgical planning, follow-up, and prognosis. When compared to FNA biopsy for MTC diagnosis, calcitonin presents higher sensibility (nearly 100\%) and specificity (95\%) (Bugalho et al. 2005). High levels of calcitonin may also occur in other medical conditions such as chronic kidney failure, hyperparathyroidism, neuroendocrine neoplasms, lung and prostate tumors and autoimmune thyroiditis (Karanikas et al. 2004, Rosario \& Calsolari 2016). Preoperative basal serum calcitonin correlates with the tumor size and extent of lymph node metastasis. Levels higher than 20,50, 200, and 500 pg/mL were associated, respectively, with metastases to lymph nodes in the ipsilateral central and ipsilateral lateral neck, the contralateral central neck, the contralateral lateral neck, and the upper mediastinum. A biochemical cure is very unlikely in patients with preoperative serum calcitonin levels higher than $1000 \mathrm{pg} / \mathrm{mL}$ (Machens \& Dralle 2010, Wells et al. 2015).

The diagnosis of hereditary MTC usually occurs in advanced stages on index cases, taking into account the development at early ages and the asymptomatic nature of the disease in the initial stages. However, the diagnosis is made in early stages or even in a premalignant phase in family members, due to the broad recommendation of genetic screening in all MEN 2 patients. Indeed, the molecular test of proband's relatives is of paramount importance since the earlier diagnosis and treatment increase the likelihood of cure of MTC (Skinner et al. 2005, Punales et al. 2008). Depending on the RET mutation, the MTC risk is classified as highest (M918T), high (C634F/G/R/S/W/Y and A883F) or moderate (all others), changing the time for initiating calcitonin level measurements and prophylactic thyroidectomy. Biochemical calcitonin monitoring might demarcate a 'window of opportunity' for pre-emptive thyroidectomy without central node dissection. For individuals harboring highest risk mutations, thyroidectomy should be performed early in life. For carriers of high-risk mutations, the thyroid surgery should be recommended before 5 years of age, whereas those carrying moderate risk mutations might be followed every 6-12 months until serum calcitonin levels became elevated (Wells et al. 2015). Of interest, recent studies indicate that some mutations, classified as moderate risk by the ATA (codons 768, 790, 804), have a more indolent clinical course with a 5-year-long expectant observation period under the premise that calcitonin levels remain within reference limits (Wells et al. 2015, Machens et al. 2018). Moreover, in a series of MEN 2A gene-carrier patients followed in a referral center in Italy, basal calcitonin levels below $60 \mathrm{pg} / \mathrm{mL}$ were always associated to an intrathyroidal MTC (Elisei et al. 2012). These observations might suggest that the ideal timing for prophylactic thyroid surgery could be individualized, taking into account patient age, type of mutation, biomarkers and imaging exams. Stimulation calcitonin tests might be useful in the decision-making process regarding prophylactic surgery (Elisei et al. 2012, Jarzab et al. 2013). Nevertheless, although extensively used in the past, recent studies found a similar accuracy between basal and stimulated calcitonin levels, indicating that the new serum calcitonin assays with improved functional sensitivity decrease the significance of stimulation tests (Elisei et al. 2012, Mian et al. 2014).

\section{Therapeutic strategies}

Surgery is the only curative treatment for MTC. Total thyroidectomy with central lymph node dissection is the procedure of choice and, depending on the serum calcitonin levels, and preoperative cervical US imaging, a more extensive surgery with lateral neck dissection should be considered (Maia et al. 2014, Wells et al. 2015, Wells 2018). Patients with intrathyroidal tumor have a 10-year survival rate of $95.6 \%$, whereas patients with regional stage disease or distant metastasis at diagnosis present overall survival rates of 75.5 and $40 \%$, respectively (Roman et al. 2006). Interestingly, the absolute number of lymph node metstases seems to impact on the chances of biochemical cure after additional surgical intervention. Scollo et al. found higher rates of calcitonin normalization in patients with less than 10 metastatic lymph nodes, as compared with those present a large number (57 vs $4 \%$ ) (Scollo et al. 2003). Recently, Sosa et al. (2017) proposed a more accurate TNM risk stratification and potential treatment selection, lowering the risk of overtreatment for patients with stage I MTC. Based on the proposed new TNM grouping, the 5-year overall survival was 94\% for stage I, 86\% for stage II, 69\% for stage III and 35\% for stage IV (Sosa et al. 2017). Patients with persistent or recurrent MTC localized to the neck are candidates for repeat neck operations. However, in the presence of widespread 
regional or metastatic disease, extensive surgery is not associated with a higher cure rate, and less aggressive procedures should be considered (Randle et al. 2017, Wells 2018). Patients with incidental, sporadic MTC and no evidence of residual disease might be safely observed after less extensive resections (Randle et al. 2017).

The presence and volume of residual disease should be assessed through calcitonin measurements to define the appropriate treatment and follow-up strategy after thyroid surgery. Distant metastases should be investigated if serum calcitonin levels are above $500 \mathrm{pg} / \mathrm{mL}$ preoperative or $150 \mathrm{pg} / \mathrm{mL}$ post-total thyroidectomy. Neck and/or chest CT, liver MRI, bone scintigraphy, and, eventually, [18F]-fluorodeoxyglucose positron emission computed tomography ( ${ }^{18} \mathrm{~F}-\mathrm{FDG}$ PET/CT) or ${ }^{18} \mathrm{~F}$-dihydroxyphenylalanine (18F-DOPA PET/CT) might be used (Maia et al. 2014, Wells et al. 2015). The 18F-DOPA PET/CT appears to be particularly useful in detecting lesions in patients with recurrent MTC and negative imaging studies (Romero-Lluch et al. 2017). The sensitivities of these tests for detecting metastatic disease vary from 50 to $80 \%$, with a lower likelihood of identifying metastatic disease in those individuals with discrete calcitonin elevation (Giraudet et al. 2007, Wells et al. 2015). Of interest, a recent study, which evaluated the performance of ${ }^{68} \mathrm{Ga}-\mathrm{PET} / \mathrm{CT}$ in detecting $\mathrm{MTC}$ lesions, indicates that it is highly sensitive in identifying bone lesions and could be a substitute for a bone scan and MRI (Castroneves et al. 2018).

In the postoperative period, calcitonin and CEA may require weeks to reach their lowest levels, so the measurement should be performed at least 2-3 months after surgery. Since serum calcitonin and CEA levels may either persist steadily high for years or rapidly increases, the calculations of their doubling times (DT; available at the ATA website https://www.thyroid.org/professionals/ calculators/thyroid-cancer-carcinoma/) are more accurate to evaluate the disease progression. The 5-year and 10-year survival rates are 25 and $8 \%$, respectively, when the doubling time is less than 6 months, and 92 and $37 \%$, respectively, when the doubling time ranges from 6 months to 2 years. The calcitonin doubling time correlates with the survival and tumor recurrence rates, providing a better predictor of survival, whereas the CEA doubling time seems to be more useful for predicting prognosis (Meijer et al. 2010).

Recently, it has been shown that dynamic risk stratification is an excellent and useful tool to acquire prognostic information and can be used to modify the initial risk estimates by the classical TNM staging.
The 5-year and 10-year recurrence rates vary from less than $1-8.5 \%$ in patients who achieve an excellent response, defined as an undetectable calcitonin level after surgery. Furthermore, the nomenclature excellent, biochemical incomplete and structural incomplete response, which has been successfully used to characterize the response to therapy and predict the clinical outcome in differentiated thyroid cancer, has also been shown to be useful in MTC (Lindsey et al. 2015, Kwon et al. 2016, Choi et al. 2018).

Other potential prognostic markers have been studied in recent years. Classically used as a marker for pancreatic neoplasms, higher levels of carbohydrate antigen (CA19.9) have been reported in patients with very aggressive MTC disease, low calcitonin levels, and increased CEA levels (Milman et al. 2011, Elisei et al. 2013a). Based on an evaluation of serum CA19.9 levels in patients with advanced structural recurrent/persistent MTC, an elevated serum CA 19.9 value appears to be a predictive factor for poor prognosis and identifies those cases with a higher risk of short-term mortality (Elisei et al. 2015). CA19.9 has also been shown to be associated with an advanced disease stage in a small pilot study (Milman et al. 2015). However, in a study conducted by our group, immunohistochemical analysis of CA19.9 was not associated with age, sex, calcitonin, CEA, or local or distant metastases (CVF Vargas, L Ceolin, AF Benine, MS Graudenz \& AL Maia unpublished observations).

\section{General therapeutic approach in metastatic MTC}

When evaluating a patient with advanced MTC, the following questions should be considered during decisionmaking: Is the patient symptomatic or asymptomatic? Is the locoregional disease controlled? Where are the metastases located? Are there lesions that require intervention due to imminent risk or associated symptoms? What is the speed of metastatic disease progression? Unfortunately, it is not always possible to get a definitive answer for some of these questions.

For patients with locally advanced disease that is not amenable to surgery or those who present distant metastasis, there is no effective therapeutic, curative option. Chemotherapy and external beam radiation therapy for the metastatic cervical recurrent disease have limited response rates (Brierley \& Tsang 1996, Nocera et al. 2000). The response rate to cytotoxic chemotherapy seems to be approximately $20 \%$, with most studies performed on limited numbers of patients and without 
robust evaluation criteria such as RECIST (Hadoux \& Schlumberger 2017). External beam radiation therapy (EBRT) may be recommended to improve locoregional control in patients at high risk of cervical relapse. Few studies have shown an improvement in locoregional control but no survival benefit, confirming that although neck disease can be controlled in high-risk patients, the progression of distant disease and subsequent death are still a significant problem (Schwartz et al. 2008, Martinez et al. 2010, Brierley \& Sherman 2012, Call et al. 2013).
Upon planning the therapeutic strategy, it is essential to keep in mind that some patients with metastatic MTC present indolent disease and good long-term prognosis, whereas others develop a progressive disease that requires close evaluation for immediate treatment. The schematic flowchart (Fig. 2) summarizes a therapeutic strategy to metastatic MTC. Expectant management can be appropriated for asymptomatic individuals with indolent, low-burden disease, whereas urgent therapy might be indicated in the presence of lesions which are

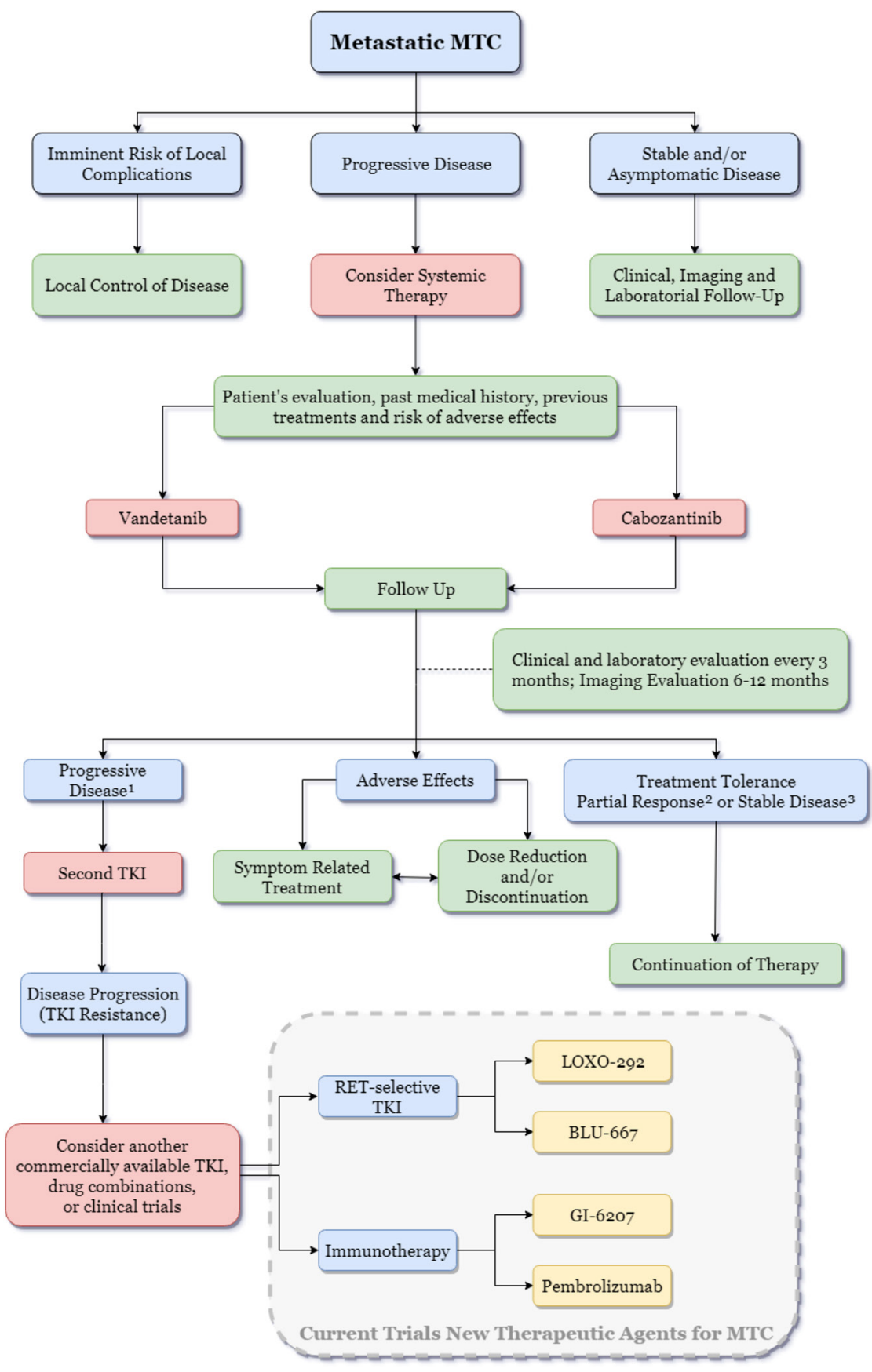

Figure 2

Schematic flowchart for the management of patients with metastatic medullary thyroid carcinoma (MTC). ${ }^{1}$ Progressive disease: $\geq 20 \%$ increase in the sum of the longest diameter of target lesions compared with the smallest-sum longest diameter recorded or the appearance of one or more new lesions; ${ }^{2}$ Partial response: $\geq 30 \%$ decrease in the sum of the longest diameters of target lesions compared with baseline; 3 Stable disease: neither partial response nor progressive disease (RECIST 1.1).
(C) 2019 Society for Endocrinology Published by Bioscientifica Ltd. Printed in Great Britain 
associated with a high risk of serious complications, such as large brain metastases, a spinal cord compression or a lesion growing into an airway or bone metastases with an imminent risk of fracture. Embolization or cryoablation may be beneficial in selected cases to decrease the tumor burden, pain, or refractory diarrhea associated with liver metastases (Fromigue et al. 2006). Localized EBRT and/or bisphosphonates administration should be considered for painful bone metastases or prevention of skeletal-related events (Beuselinck et al. 2012, Farooki et al. 2012).

Patients with advanced MTC may experience paraneoplastic debilitating diarrhea due to hypersecretion of calcitonin, VIP (Cox et al. 1979), or increases on intestinal motility (Rambaud et al. 1988). Antimotility agents (loperamide or codeine) may be initially used as first-line therapy. Further options for unsuccessful cases include somatostatin analogs (Mahler et al. 1990, Zatelli et al. 2006). For those patients with extensive liver metastases, surgical resection, percutaneous radiofrequency ablation, or arterial chemoembolization might be considered in an attempt to reduce the calcitonin levels (Fromigue et al. 2006). The most common ectopic hormones, CRH or ACTH, can rarely cause paraneoplastic Cushing's syndrome $(0.7 \%$ cases), accounting for up to 2-6\% of ectopic Cushing's syndrome cases (Barbosa et al. 2005). Until recently, the management of this challenging situation, associated to extreme morbidity and mortality, was limited to surgical removal of metastatic disease, medical therapy with anti-adrenal compounds or bilateral adrenalectomy. Nevertheless, recent reports indicate successful treatment of MTC-related Cushing syndrome with TKIs (Barroso-Sousa et al. 2014, Nella et al. 2014).

\section{Systemic therapy for advanced MTC}

\section{General overview}

Cumulative knowledge regarding the distinct signaling pathways and multiple genetic abnormalities involved in the pathogenesis of cancer has allowed the development of targeted molecular therapies. Protein kinases are characterized by their ability to catalyze the phosphorylation of tyrosine amino acid residues in proteins, activating the various intracellular signaling pathways, cell proliferation, differentiation, migration, and anti-apoptosis. Therefore, tyrosine kinase inhibitors (TKIs) may provide a therapeutic benefit in cancer by blocking tyrosine kinase-dependent oncogenic pathways. TKIs can be specific to inhibit one or several tyrosine kinase receptors (multikinase inhibitors, MKIs) (Lemmon \& Schlessinger 2010, Broekman et al. 2011).

\section{Signaling pathways implicated in medullary thyroid cancer}

Uncontrolled tyrosine kinase receptor activation is one of the primary mechanisms of cancer development and progression. In normal thyroid $\mathrm{C}$ cells, signaling pathways such as RET, RAS/MAPK, PI3K, c-MET, and mTOR modulate a wide range of intracellular processes, including cell proliferation, differentiation, migration, and apoptosis. Diverse molecular-driven alterations in these signaling pathways are involved in thyroid carcinogenesis (Santarpia et al. 2010, Mulligan 2014). The role of RET tyrosine kinase receptor in MTC pathogenesis has been well documented. Vascular endothelial growth factor (VEGF) and hepatocyte growth factor (c-MET), as well as their tyrosine kinase receptors, are overexpressed in MTC and play critical roles in pathogenesis, progression, and disease recurrence (Papotti et al. 2000, Capp et al. 2010).

\section{RET pathway}

Hereditary MTC is caused by gain-of-function mutations of the RET receptor that lead to constitutive RET kinase activity. In this oncogenic mechanism, MEN 2A-related mutations activate RET by inducing disulfide-linked homodimerization, in which a cysteine residue is mutated to a noncysteine residue, and a partner cysteine that is involved in the formation of a disulfide bond become free and form an aberrant intermolecular disulfide bond between two mutants RET. In MEN 2B mutations, which occur in the tyrosine kinase 2 domain, RET is activated in monomeric form, probably due to a conformational change in the catalytic core of the kinase domain. These mutations increased ATP-binding and kinase activity, allowing robust activation of downstream signals (Mulligan 2018).

The RET gene was identified in 1985 by Takahashi and cols, mapping on 10q11.2 and containing 21 exons spanning a region of 55,000 bp (Takahashi et al. 1985). RET is a member of the cadherin superfamily and encodes a tyrosine kinase receptor, which is a cell-surface molecule that transduces signals for cell growth, proliferation, differentiation, migration, survival, and apoptosis. RET proteins are derived from a single polypeptide core of $120 \mathrm{kDa}$ and modified to $150 \mathrm{kDa}$ and $170 \mathrm{kDa}$ by post-translational glycosylation. Only the fully mature 
glycosylated $170-\mathrm{kDa}$ RET protein isoform is present on the cell surface, whereas the immature $150-\mathrm{kDa}$ isoform is confined to the Golgi (Takahashi et al. 1991, 1993). Alternative splicing of the RET gene results in the RET51, RET43 and RET9 isoforms, which differ at their carboxyl termini (Tahira et al. 1990, Myers et al. 1995, Carter et al. 2001).

The RET receptor comprises three domains: an extracellular, a transmembrane, and an intracellular domain. The extracellular domain includes regions that are homologous to the cadherin family of cell adhesion (cadherin-like) molecules that induce and stabilize conformational changes needed for interactions with the ligands and coreceptors and a large region enriched in cysteine residues (cysteine-rich region), which is responsible for the tertiary structure and formation of dimers. The intracellular domain contains two tyrosine kinase domains (TK1 and TK2) that are separated by 28 amino acids. These subdomains contain the tyrosine residues are phosphorylated during receptor activation and are involved in the activation of the signaling pathways (Takahashi et al. 1988). The tyrosine residues 905, 1015, 1062 are conserved in all three RET isoforms, but the tyrosine residue 1096 is present only in the long (RET 51) isoform.

RET is a receptor tyrosine kinase essential for the normal development and maturation of different tissues. Under normal conditions, RET is activated by a group of proteins of the glial cell line-derived neurotrophic factor (GDNF) family ligands (GFLs), including GDNF, neurturin (NRTN), artemin (ARTN), and persephin (PSPN). RET does not directly bind to GFLs, requiring an additional coreceptor, a GDNF family receptor- $\alpha$ (GFR $\alpha)$. The GFL-GFR $\alpha$ complex binds to RET, inducing RET dimerization and a subsequent autophosphorylation on multiple tyrosine residues within the intracellular tyrosine kinase domain (Airaksinen \& Saarma 2002).

Studies using transgenic mouse models have demonstrated that Ret oncogenes can drive MTC development. Mice expressing Ret-C634R or Ret-M918T under the control of the calcitonin gene promoter developed MTC (Michiels et al. 1997, Acton et al. 2000). Additionally, transgenic mice carrying Ret-C634R under the control of a ubiquitous viral promoter developed MTC, suggesting that murine C cells are highly susceptible to RET-mediated transformation (Kawai et al. 2000). However, knock-in of the M918T mutation into the mouse endogenous Ret gene caused CCH but not MTC, suggesting that, in the background of a normally expressed Ret-mutant allele, the accumulation of secondary genetic alterations is required for the development of MTC (Smith-Hicks et al. 2000).

Interestingly, RET protein has been shown to induce cell death in the absence of their ligands (GFL-GFR $\alpha$ ), while in the presence of their ligands a completely different signal is transduced. In the absence of ligand, RET exerts pro-apoptotic activity, and the addition of GDNF is then sufficient to block RET apoptotic activity. This finding implies that a single mutation may simultaneously induce increased mitogenic signaling and reduce pro-apoptotic activity (Bordeaux et al. 2000).

\section{RAS pathway}

RAS gene mutations have been found in 0-68\% RETnegative MTC (Moura et al. 2011, 2015, Ciampi et al. 2013), and a recent meta-analysis has shown that the RAS mutation appears to lack significant prognostic value in predicting tumor aggressiveness (Vuong et al. 2018). In our center, we identified a mutation in exon 2 of H-RAS in $3.8 \%$ of patients with sporadic MTC, $70 \%$ of whom were positive for somatic M918T in RET (CV Ferreira \& AL Maia unpublished observations). The oncogenic $R A S$ mutations and mutations in other components of the RAS/MAPK signaling pathway appear to be mutually exclusive events in most tumors, indicating that the deregulation of Ras-dependent signaling is an essential requirement for tumorigenesis (Moura et al. 2011, Ciampi et al. 2013, Nikiforova et al. 2013).

RAS genes (H-RAS, chromosome 11; K-RAS, chromosome 12 and $N-R A S$, chromosome 1) encode highly related G-proteins that play a central role in intracellular signal transduction by activation of the MAPK and other signaling pathways, such as PI3K/AKT (Santarpia et al. 2010, Fernandez-Medarde \& Santos 2011). The H-RAS, K-RAS, and N-RAS genes all have a similar exonic structure, and therefore, all probably derive from a common, spliced ancestral gene (Shimizu et al. 1983).

The molecular mechanism proposed for RAS-derived tumorigenesis is the constitutive activation of distinct pathways that are linked to the functional control of a vast assortment of cellular outcomes, including cell cycle progression, growth, migration, cytoskeletal changes, apoptosis, and senescence (Santarpia et al. 2010, Fernandez-Medarde \& Santos 2011). The ras-mutated protein mediates its effects on cellular proliferation in part by activation of a cascade of kinases: RAF (A-RAF B-RAF and C-RAF), dual-specificity mitogen-activated protein kinases (MEK1/2), extracellular signal-regulated kinases (ERK1/2) and p38 mitogen-activated protein kinase. 
RAS also activates the PI3K pathway via direct interaction with the catalytic subunit of the protein. PI3K activation leads to the accumulation of the second messenger, phosphatidylinositol 3,4,5-trisphosphate (PIP3), resulting in pyruvate dehydrogenase kinase isozyme 1 (PDK1) and v-akt murine thymoma viral oncogene homolog (AKT) activation (Krasilnikov 2000, Vojtek and Der 1998).

\section{MET pathway}

Overexpression of MET and co-expression of HGF-MET has been reported in MTC tumors and has been associated with multifocality (Papotti et al. 2000, Ricarte-Filho et al. 2009). Silencing of the MET proto-oncogene has resulted in the impairment of the execution of the fully invasive growth program in vitro, lack of tumor growth and decreased generation of experimental metastases in vivo (Corso et al. 2008). Crosstalk has been demonstrated between MET and RET at transcriptional and signaling levels, leading to the promotion of thyroid cell transformation and invasive phenotypes (Cassinelli et al. 2009, Bentzien et al. 2013).

The MET proto-oncogene is located on chromosome 7q21-31 and encodes a single-pass tyrosine kinase protein. MET kinase is a cell-surface receptor for hepatocyte growth factor (HGF), a cytokine that conveys a unique combination of pro-migratory, anti-apoptotic, and mitogenic signals expressed in the epithelial cells of many organs during embryogenesis and in adulthood (liver, pancreas, prostate, kidney, muscle, and bone marrow) (Cooper \& Spaulding 1984, Gonzatti-Haces et al. 1986, Park et al. 1986). In tumor cells, MET activation triggers a diverse series of signaling cascades resulting in cell growth, proliferation, invasion, and protection against apoptosis (Birchmeier et al. 2003, Liu et al. 2008). Signaling for growth and mitogenesis occurs via the RAS-MAPK signaling pathway and plays an essential role in the epithelial-to-mesenchymal transition that results from loss of intracellular adhesion via cadherins and integrins, with a change in cell shape (Boccaccio \& Comoglio 2006).

\section{mTOR pathway}

The oncogenic RET activity in MTC seems to be partially modulated by overactivation of the PI3K/Akt/mTOR pathway (Drosten et al. 2004). Interestingly, studies have shown that mTOR has a higher activation in lymph node metastases than in primary MTC and that the expression of eiF4E has a strong correlation with the tumor stage, suggesting a role of mTOR in tumor progression (Kouvaraki et al. 2011, Tamburrino et al. 2012). Besides, mTOR activation appears to be an early event in C-cell transformation, playing a role early in the MTC tumorigenic process (Tamburrino et al. 2012).

The $m T O R$ gene is located on chromosome 1 p36.22 and contains 60 exons. $m T O R$ encodes a serine/threonine kinase, in the family of phosphatidylinositol kinaserelated kinases, which is involved in the regulation of cell proliferation, apoptosis, the cell cycle, angiogenesis, metabolism, and protein synthesis (Meric-Bernstam \& Gonzalez-Angulo 2009). mTOR functions as part of 2 structurally and functionally distinct signaling complexes: mTOR complex 1 (mTORC1), which consists of mTOR, mammalian LST8 (mLST8), proline-rich Akt substrate 40 (PRAS40), and raptor; mTOR complex 2 (mTORC2), which includes mTOR, mLST8 (G $\beta \mathrm{L}$ ), mSIN1, PRR5 (protor), and Rictor (Jacinto et al. 2006, Wullschleger et al. 2006, Martin et al. 2008).

The deregulation of mTOR pathway activation is observed in several types of cancer. The main pathway of mTOR activation is PI3K/Akt. Specific growth factors are responsible for stimulating RTKs that lead to PI3K/ Akt activation. Once these receptors are stimulated, PI3K is recruited and catalyzes the conversion of phosphatidylinositol 4,5-bisphosphate (PIP2) to phosphatidylinositol 3,4,5-triphosphate (PIP3) and thus activates Akt. The control of Akt activation and, consequently of mTOR, is done by PTEN, a tumor suppressor that converts PIP3 to PIP2 thus inhibiting the activation of Akt (Sekulic et al. 2000, Meric-Bernstam \& Gonzalez-Angulo 2009).

\section{Molecular target therapy: multikinase inhibitors}

The advances in knowledge of the molecular mechanisms and intracellular signaling pathways involved in MTC pathogenesis have allowed the development of target therapy, promoting noteworthy developments and new perspectives on metastatic MTC therapy.

Several multikinase inhibitors (MKI) compounds have been tested for MTC treatment, including motesanib (Schlumberger et al. 2009), sorafenib (Lam et al. 2010, de Castroneves et al. 2016), sunitinib (Carr et al. 2010), axitinib (Cohen et al. 2008), imatinib (de Groot et al. 2007), pazopanib (Bible et al. 2014), anlotinib (Sun et al. 2018), lenvatinib (Haugen et al. 2016), vandetanib (Wells et al. 2012), and cabozantinib (Elisei et al. 2013b) (Fig. 1).
(C) 2019 Society for Endocrinology Published by Bioscientifica Ltd. Printed in Great Britain 
Because patients with metastatic MTC may present indolent disease and long life expectancy, prospective trials use surrogates than overall survival (OS) to evaluate drug efficacy. The objective response rate (ORR) and the progression-free survival (PFS) are the most used outcomes since they show a better correlation with OS (Hadoux \& Schlumberger 2017).

Vandetanib and cabozantinib are the only MKIs approved for advanced MTC treatment. The first approved compound, vandetanib, selectively targets RET, VEGF, and epidermal growth factor (EGF) receptors (Wedge et al. 2002). The efficacy of vandetanib was evaluated in 331 individuals with metastatic MTC who were randomized to receive vandetanib $(300 \mathrm{mg}$ ) or placebo (Wells et al. 2012). The results showed a significant increase in PFS in the vandetanib-treated group (30.2 vs 19.2 months; $\mathrm{HR}=0.46,95 \% \mathrm{CI}=0.31-0.69)$ Vandetanib has also been successfully used to treat children with MEN 2B (Fox et al. 2013). The second approved compound, cabozantinib, is a c-MET, VEGFR2, and RET MKI. A randomized study of 330 individuals with documented MTC progression demonstrated a significant increase in PFS in the cabozantinib-treated group (11.2 vs 4.0 months; $\mathrm{HR}=0.28$, 95\% CI $=0.19-0.40, P<0.0001$ ) (Elisei et al. 2013b). The effect of vandetanib or cabozantinib on the survival of MTC patients remains unknown, but interim analyses have not revealed any differences between the two drugtreated and placebo groups (Wells et al. 2012, Elisei et al. 2013b).

Lenvatinib, an MKI of the VEGFR-1, 2, and 3, FGFR-1-4, PDGFRa, RET, and KIT signaling networks, was evaluated in a phase 2 trial. Fifty-nine patients with unresectable progressive MTC were included in that study. The disease control rate was 80\% (95\% CI: 67-89\%), which is the highest reported rate to date. Of interest, the objective response rate (ORR) was similar between patients with (35\%) and without (36\%) prior anti-VEGFR therapy, confirming the lack of cross-resistance among MKIs (Haugen et al. 2016).

Given that RET and RAS activate the PI3K/AKT/mTOR pathway, a small phase 2 trial was conducted to evaluate the efficacy of everolimus, an mTOR inhibitor approved for the treatment of neuroendocrine tumors and renal cell carcinoma, in patients with progressive metastatic or inoperable MTC (Schneider et al. 2015). Seven patients were enrolled, of whom five (71\%) showed stable disease. The median PFS was 33 weeks, and no objective responses were observed. Similar findings were observed in another everolimus phase 2 trial that included 9 MTC patients (Lim et al. 2013), indicating that everolimus alone has limited activity against MTC. Nevertheless, promising data have been reported from a phase 2 trial in patients with progressive, advanced thyroid cancer who received everolimus in combination with sorafenib (Sherman et al. 2016). In another report, everolimus was prescribed in addition to vandetanib in a patient who presented disease progression and observed a $25 \%$ tumor reduction (Heilmann et al. 2016). The combination of RET kinase inhibitors and mTOR inhibitors might be an exciting dual targeting strategy, but it awaits further evaluation in clinical trials.

A limitation of MKI therapy is that the tumor cells might develop an escape mechanism, allowing the tumor to start to grow again after a variable period of treatment. This phenomenon is independent of the type of MKI used or tumor treated (Arao et al. 2011). Secondary mutations in the kinase domains that sterically block the binding of MKIs, usually downstream from the TKI target, or in parallel pathways that result in a mechanism to bypass the action of the drug, have been demonstrated in other tumors, but is still unclear in MTC (Viola et al. 2016, Liu et al. 2018). Interestingly, a suggestive case of an acquired RET V804M gatekeeper resistance mutation to vandetanib has been described (Subbiah et al. 2018b). In such cases, a second MKI might be considered. Of note, the discontinuation of an MKI treatment could lead to a rapid increase in tumor growth and disease progression (Resteghini et al. 2017, Trimboli et al. 2018).

\section{Mutational profile and response to multikinase inhibitor therapy}

Several recent studies have indicated the potential clinical relevance of the identification of oncogenic driver alterations on molecular target therapeutic strategy. In the phase III trial of vandetanib, patients with sporadic MTC harboring a somatic RET M918T mutation had a higher response rate to vandetanib as compared with patients without this mutation ( 54.5 vs $32 \%$ ), although the results were inconclusive due to the small sample size (Wells et al. 2012).

In the cabozantinib phase III trial, patients with RET mutation exhibited a longer PFS when compared with the placebo group (60 vs 20 weeks), with the subgroup of patients harboring RET M918T achieving the greatest PFS (61 vs 17 weeks). Patients with RAS mutations treated with cabozantinib also exhibited a longer PFS when compared with those treated with placebo (Sherman et al. 2016). Subsequent exploratory analyses have shown a 
statistically nonsignificant increase in the OS on the group who received cabozantinib as compared with placebo. Of note, the most significant benefits of cabozantinib treatment were observed in patients with RET M918T positive tumors (Hadoux \& Schlumberger 2017). Despite these findings, there is no specific recommendation for treatment based on RET status. Some patients without documented RET mutations have benefited from MKI therapy. In vitro studies have shown that RET codon 804 and 806 mutations confer resistance to vandetanib therapy (Carlomagno et al. 2004, 2009).

MTC is a highly vascularized tumor, and overexpression of VEGF and its coreceptors have already been shown in MTC samples (Capp et al. 2010). Angiogenesis is critical for tumor growth, and the MKI anti-angiogenic effect is likely to play a role in response to therapy. Of interest, angiogenesis appears to be more intense in RET positive tumors, a feature that might increase their susceptibility to antiangiogenic treatment (Verrienti et al. 2016).

\section{The choice of the first-line drug}

The chronic use and side-effect profiles of MKIs must be taken into account when selecting patients since it is not clear which patients will benefit the most from TKI therapy. The criteria for initiating therapy include a high tumor burden and a rapid rate of disease progression, tumor involvement that threatens vital structures that cannot be managed by localized therapy. Only a selected group of patients with metastatic MTC should be considered for systemic therapy (Fig. 3).

Despite the established benefits of MKI for PFS, it is essential to consider the several adverse effects often noticed during their use and how much they can impact the patients' life quality. The majority of MKI-related adverse events are familiar among the different drugs. The most frequent adverse events are diarrhea, rash, fatigue, and nausea. The most common AEs are usually of mild intensity (grade 1 or 2 ) and can be easily prevented or managed with symptom-related treatment, but in a nonnegligible percentage of cases, dose reduction (up to 79\% for cabozantinib and 35\% for vandetanib) was needed in clinical trials (Elisei et al. 2013b, Viola et al. 2016). MKIinduced hypothyroidism is also frequent and requires an increase in the levothyroxine dose. Adverse events might be severe or life-threatening (G3-G4) in 5-10\% of cases. MKIrelated grade 5 adverse events have also been reported (de Groot et al. 2007, Schlumberger et al. 2009, Lam et al. 2010, Wells et al. 2012, Elisei et al. 2013b, Scheffel et al. 2013,

(c) 2019 Society for Endocrinology Published by Bioscientifica Ltd. Printed in Great Britain

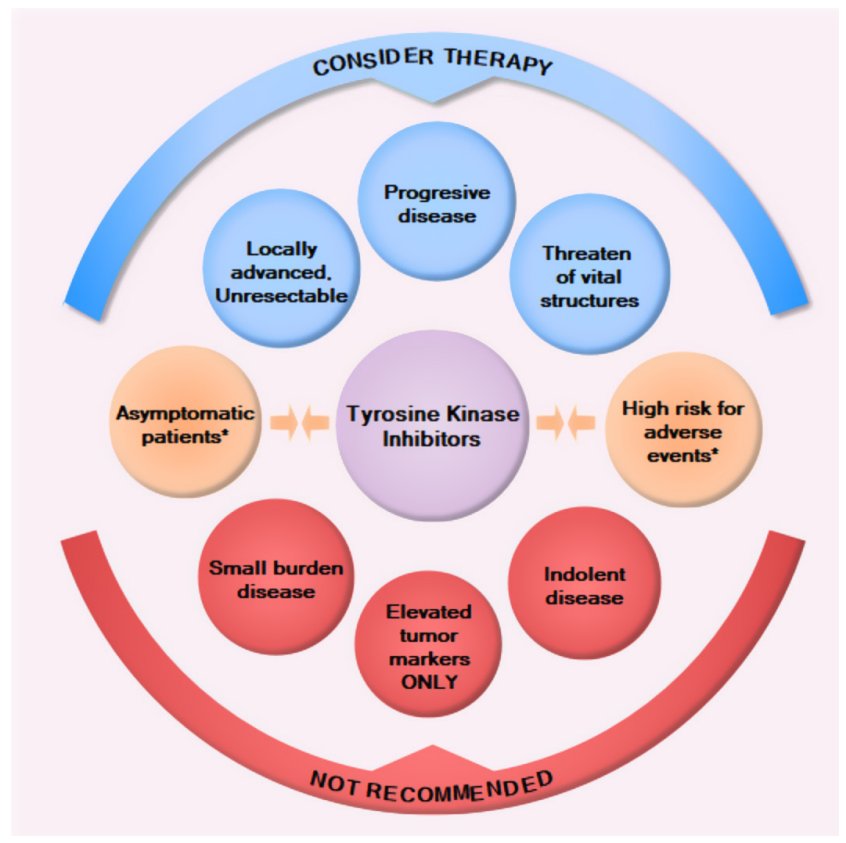

Figure 3

Schematic diagram of the main aspects of disease presentation to be considered before recommend or not MKI therapy in patients with metastatic medullary thyroid carcinoma. *Evaluate case-by-case basis considering patients concomitant medical conditions, medical history, as well as the patient quality of life and lifestyle.

Haugen et al. 2016). Of interest, recent studies examining the use of vandetanib and sorafenib outside of a clinical trial have reported similar adverse event profiles (Chougnet et al. 2015, de Castroneves et al. 2016).

In addition to the different side-effect profiles of the MKIs, the attending physician must also take into account the patient's risk factors, past medical history, and adverse effect tolerance (Maia et al. 2017). Particular caution should be taken when prescribing MKIs for patients with a medical history of hemoptysis and hemorrhages, tumor invading vital structures of the neck, radiation treatment of the neck or mediastinum since they may be at higher risk for hemorrhages and fistula formation, a rare but life-threatening antiangiogenic MKI adverse event (Blevins et al. 2014). Vandetanib carries a higher risk for prolongation of the QT interval and should be avoided in patients with heart conduction disorders (Massicotte et al. 2013, Cabanillas et al. 2014). The use of vandetanib would be a better choice for patients whose occupation requires the use of the hands (e.g., carpenters, musicians) since the hand-foot syndrome is a common side effect of cabozantinib (Bastholt et al. 2016, Maia et al. 2017). The management of side effects related to MKI is essential to maximize the clinical benefits and increase the patient's quality of life (Grande et al. 2013, Bastholt et al. 2016). 


\section{Selective TKIs}

Despite the advances in the management of metastatic MTC in the last decade, the clinical experience with the MKIs has been somewhat disappointing. While MKIs have increased the PFS, there was no improvement in OS. Almost all studies have shown a relatively low rate of partial responses, absence of complete response, and eventual tumor progression due to acquired drug resistance, which most commonly is due to secondary mutations in the kinase domains that sterically block the binding of MKIs in the target genes (Liu et al. 2018). These drawbacks of MKI therapy may be partially explained by 'off-target' side effects that limit the drug doses and consequently the degree of RET-specific inhibition. The vast and common adverse effects of MKIs results from concurrent inhibition of other targets, such as VEGFR2/KDR and lead to dose reductions or discontinuation (Romei et al. 2016, Wells 2018). Recently, new next-generation small-molecule TKIs designed for highly potent and selective targeting of oncogenic RET alterations have been developed with the goal of promoting a potent RET pathway inhibition and improve the pharmacokinetic properties of the currently available MKIs (Subbiah et al. 2018b).

\section{LOXO-292 and BLU-667}

LOXO-292 is an orally bioavailable compound, selective and highly active RET inhibitor in preclinical models of RET-altered cancers in vitro and in vivo. In contrast to MKIs, LOXO-292 retains nanomolar potency against various RET alterations, with potential antineoplastic activity. A phase 1 study was designed to evaluate the safety, tolerability, pharmacokinetics and preliminary anti-tumor activity of LOXO-292 in patients with advanced solid tumors. The study included 82 patients, including 29 RET-mutant MTC tumors. The ORR in MTC patients was 45\% (CI 95\%: $24-68 \%)$. Tumor reduction was achieved in (9/20) $49 \%$ of MTC tumors, including a patient with a RET V804M mutation, and MKI-pretreated patients. Ninety percent $(19 / 24)$ of the MTCs had a $\geq 50 \%$ decrease in serum calcitonin. Overall, the compound appeared to be well tolerated among the patients. AEs $(\geq 10 \%)$ were fatigue (20\%), diarrhea (16\%), constipation (15\%), dry mouth $(12 \%)$, nausea (12\%) and dyspnea (11\%). Only two treatment-related AEs $\geq$ grade 3 were reported: tumor lysis syndrome (DLT) and increased ALT. Most MTC patients (93\%; 27/29) remained on treatment (ClinicalTrials.gov Identifier: NCT03157128) (Subbiah et al. 2018b).
BLU-667 is also a highly selective RET inhibitor. In vitro, BLU-667 demonstrated $\geq 10$-fold increased potency over approved MKIs against oncogenic RET variants and resistance mutants. In vivo, BLU-667 potently inhibited the growth of thyroid cancer xenografts driven by various RET mutations and fusions without VEGFR-2 inhibition. The closest BLU-667 kinase off-target identified was Janus kinase 1 (JAK1). To investigate the clinical impact of BLU-667, a phase I, first-in-human, the dose-escalation study was conducted (ClinicalTrials.gov Identifier: NCT03037385). Fifty-one patients were enrolled with unresectable advanced solid tumors. Of them, 29 patients were found to have RET-mutant MTC. Overall, BLU-667 appeared to be well tolerated among the patients. The most common AE was grade 1 constipation (23\%). Grades 3 to 4 AEs were also found, including hypertension (8\%) and neutropenia (4\%). Additional AEs included fatigue, diarrhea and a decrease in white blood cells ( $2 \%$ each). There were no reports of grades $4 / 5$ AEs (Subbiah et al. 2018a). Of interest, the potential side effects of JAK inhibition (reduced reticulocytes, red blood cells, neutrophils/monocytes) has not been observed among the patients tested, suggesting the preferential activity of BLU-667 for RET versus JAK.

\section{Immunotherapy}

In the last few years, immunotherapy has transitioned from a promising to a well-established option as an oncological treatment for several types of malignancies, acting as an immune checkpoint inhibitor (Emens et al. 2017). Preclinical studies on MTC have revealed potential new treatments through the use of immunotherapy (Naoum et al. 2018). Several ongoing trials are investigating this type of therapy, including a phase II trial studying a therapy directed toward cells presenting CEA (GI-6207), a therapy focused on programmed death ligand 1 (PDL1) with the use of pembrolizumab (Arasanz et al. 2017). Despite the lack of published results regarding the efficacy of these compounds on advanced MTC, all of these drugs have the potential to serve as new treatments.

\section{Conclusion and perspectives}

MTC is a very rare cancer with a good prognosis when diagnosed at early stages. For patients with advanced (c) 2019 Society for Endocrinology Published by Bioscientifica Ltd. Printed in Great Britain 
or metastatic disease, there is no effective therapeutic, curative option. In recent years, MKI therapy led to increases in the PFS, but no changes in the OS have been demonstrated to date. These compounds commonly cause toxicity, and it is crucial to establish an appropriate stratification of the clinical risk of patients to whom these drugs will be administered. The relatively low rate of partial responses and eventual tumor progression indicate the need to synergistic combinations of therapeutic targets whereas significant off-target toxicities may occur, limiting the degree of TKI-specific inhibition. Recently, next-generation small-molecule TKIs designed for highly potent and selective targeting of oncogenic RET alterations have been developed, and with the emergence of immunotherapy as an effective cancer treatment, there is hope for new promising drugs for the treatment of advanced MTC.

\section{Declaration of interest}

A L M has served as an advisor/speaker for Sanofi-Genzyme within the past 2 years. A L M and C V F V have served as principal investigator and coordinator, respectively, in multicenter studies for Astra-Zeneca and Sanofi-Genzyme within the past 2 years. The other authors have nothing to disclose.

\section{Funding}

This work was supported by grants from Coordenação de Aperfeiçoamento de Pessoal de Nível Superior (CAPES), Conselho Nacional de Desenvolvimento Científico e Tecnológico (CNPq), Fundação de Amparo à Pesquisa do Estado do Rio Grande do Sul (PRONEX/FAPERGS).

\section{References}

Acton DS, Velthuyzen D, Lips CJ \& Hoppener JW 2000 Multiple endocrine neoplasia type 2B mutation in human RET oncogene induces medullary thyroid carcinoma in transgenic mice. Oncogene 19 3121-3125. (https://doi.org/10.1038/sj.onc.1203648)

Airaksinen MS \& Saarma M 2002 The GDNF family: signalling, biological functions and therapeutic value. Nature Reviews: Neuroscience 3 383-394. (https://doi.org/10.1038/nrn812)

Arao T, Matsumoto K, Furuta K, Kudo K, Kaneda H, Nagai T, Sakai K, Fujita Y, Tamura D, Aomatsu K, et al. 2011 Acquired drug resistance to vascular endothelial growth factor receptor 2 tyrosine kinase inhibitor in human vascular endothelial cells. Anticancer Research $\mathbf{3 1}$ 2787-2796.

Arasanz H, Gato-Canas M, Zuazo M, Ibanez-Vea M, Breckpot K, Kochan G \& Escors D 2017 PD1 signal transduction pathways in T cells. Oncotarget 8 51936-51945. (https://doi.org/10.18632/ oncotarget.17232)

Barbosa SL, Rodien P, Leboulleux S, Niccoli-Sire P, Kraimps JL, Caron P, Archambeaud-Mouveroux F, Conte-Devolx B, Rohmer V \& Groupe d'Etude des Tumeurs Endocrines 2005 Ectopic adrenocorticotropic hormone-syndrome in medullary carcinoma of the thyroid: a retrospective analysis and review of the literature. Thyroid $\mathbf{1 5}$ 618-623. (https://doi.org/10.1089/thy.2005.15.618)

Barroso-Sousa R, Lerario AM, Evangelista J, Papadia C, Lourenco Jr DM, Lin CS, Kulcsar MA, Fragoso MC \& Hoff AO 2014 Complete resolution of hypercortisolism with sorafenib in a patient with advanced medullary thyroid carcinoma and ectopic ACTH (adrenocorticotropic hormone) syndrome. Thyroid 24 1062-1066. (https://doi.org/10.1089/thy.2013.0571)

Bastholt L, Kreissl MC, Fuhrer D, Maia AL, Locati LD, Maciel L, Wu Y, Heller KN, Webster A \& Elisei R 2016 Effect of an outreach programme on vandetanib safety in medullary thyroid cancer. European Thyroid Journal 5 187-194. (https://doi. org/10.1159/000448919)

Bentzien F, Zuzow M, Heald N, Gibson A, Shi Y, Goon L, Yu P, Engst S, Zhang W, Huang D, et al. 2013 In vitro and in vivo activity of cabozantinib (XL184), an inhibitor of RET, MET, and VEGFR2, in a model of medullary thyroid cancer. Thyroid 23 1569-1577. (https:// doi.org/10.1089/thy.2013.0137)

Beuselinck B, Wolter P, Karadimou A, Elaidi R, Dumez H, Rogiers A, Van Cann T, Willems L, Body JJ, Berkers J, et al. 2012 Concomitant oral tyrosine kinase inhibitors and bisphosphonates in advanced renal cell carcinoma with bone metastases. British Journal of Cancer $\mathbf{1 0 7}$ 1665-1671. (https://doi.org/10.1038/bjc.2012.385)

Bible KC, Suman VJ, Molina JR, Smallridge RC, Maples WJ, Menefee ME, Rubin J, Karlin N, Sideras K, Morris JC, 3rd, et al. 2014 A multicenter phase 2 trial of pazopanib in metastatic and progressive medullary thyroid carcinoma: MC057H. Journal of Clinical Endocrinology and Metabolism 99 1687-1693. (https://doi.org/10.1210/jc.2013-3713)

Birchmeier C, Birchmeier W, Gherardi E \& Vande Woude GF 2003 Met, metastasis, motility and more. Nature Reviews: Molecular Cell Biology 4 915-925. (https://doi.org/10.1038/nrm1261)

Blevins DP, Dadu R, Hu M, Baik C, Balachandran D, Ross W, Gunn B \& Cabanillas ME 2014 Aerodigestive fistula formation as a rare side effect of antiangiogenic tyrosine kinase inhibitor therapy for thyroid cancer. Thyroid 24 918-922. (https://doi.org/10.1089/thy.2012.0598)

Boccaccio C \& Comoglio PM 2006 Invasive growth: a MET-driven genetic programme for cancer and stem cells. Nature Reviews: Cancer 6 637-645. (https://doi.org/10.1038/nrc1912)

Bordeaux MC, Forcet C, Granger L, Corset V, Bidaud C, Billaud M, Bredesen DE, Edery P \& Mehlen P 2000 The RET proto-oncogene induces apoptosis: a novel mechanism for Hirschsprung disease. EMBO Journal 19 4056-4063. (https://doi.org/10.1093/ emboj/19.15.4056)

Borrego S, Saez ME, Ruiz A, Gimm O, Lopez-Alonso M, Antinolo G \& Eng C 1999 Specific polymorphisms in the RET proto-oncogene are over-represented in patients with Hirschsprung disease and may represent loci modifying phenotypic expression. Journal of Medical Genetics 36 771-774. (https://doi.org/10.1136/jmg.36.10.771)

Brandi ML, Gagel RF, Angeli A, Bilezikian JP, Beck-Peccoz P, Bordi C, Conte-Devolx B, Falchetti A, Gheri RG, Libroia A, et al. 2001 Guidelines for diagnosis and therapy of MEN type 1 and type 2 . Journal of Clinical Endocrinology and Metabolism 86 5658-5671. (https://doi.org/10.1210/jcem.86.12.8070)

Brierley J \& Sherman E 2012 The role of external beam radiation and targeted therapy in thyroid cancer. Seminars in Radiation Oncology 22 254-262. (https://doi.org/10.1016/j.semradonc.2012.03.010)

Brierley JD \& Tsang RW 1996 External radiation therapy in the treatment of thyroid malignancy. Endocrinology and Metabolism Clinics of North America 25 141-157. (https://doi.org/10.1016/S08898529(05)70316-9)

Broekman F, Giovannetti E \& Peters GJ 2011 Tyrosine kinase inhibitors: multi-targeted or single-targeted? World Journal of Clinical Oncology 2 80-93. (https://doi.org/10.5306/wjco.v2.i2.80)

Bugalho MJ, Santos JR \& Sobrinho L 2005 Preoperative diagnosis of medullary thyroid carcinoma: fine needle aspiration cytology as https://erc bioscientifica com

https://doi.org/10.1530/ERC-18-0574 (c) 2019 Society for Endocrinology Published by Bioscientifica Ltd. Printed in Great Britain 
compared with serum calcitonin measurement. Journal of Surgical Oncology 91 56-60. (https://doi.org/10.1002/jso.20269)

Cabanillas ME, Hu MI \& Jimenez C 2014 Medullary thyroid cancer in the era of tyrosine kinase inhibitors: to treat or not to treat - and with which drug - those are the questions. Journal of Clinical Endocrinology and Metabolism 99 4390-4396. (https://doi. org/10.1210/jc.2014-2811)

Call JA, Caudill JS, McIver B \& Foote RL 2013 A role for radiotherapy in the management of advanced medullary thyroid carcinoma: the mayo clinic experience. Rare Tumors 5 e37. (https://doi.org/10.4081/ rt.2013.e37)

Capp C, Wajner SM, Siqueira DR, Brasil BA, Meurer L \& Maia AL 2010 Increased expression of vascular endothelial growth factor and its receptors, VEGFR-1 and VEGFR-2, in medullary thyroid carcinoma. Thyroid 20 863-871. (https://doi.org/10.1089/thy.2009.0417)

Carlomagno F, Guida T, Anaganti S, Vecchio G, Fusco A, Ryan AJ, Billaud M \& Santoro M 2004 Disease associated mutations at valine 804 in the RET receptor tyrosine kinase confer resistance to selective kinase inhibitors. Oncogene 23 6056-6063. (https://doi.org/10.1038/ sj.onc.1207810)

Carlomagno F, Guida T, Anaganti S, Provitera L, Kjaer S, McDonald NQ, Ryan AJ \& Santoro M 2009 Identification of tyrosine 806 as a molecular determinant of RET kinase sensitivity to ZD6474. Endocrine-Related Cancer 16 233-241. (https://doi.org/10.1677/ERC08-0213)

Carr LL, Mankoff DA, Goulart BH, Eaton KD, Capell PT, Kell EM, Bauman JE \& Martins RG 2010 Phase II study of daily sunitinib in FDG-PET-positive, iodine-refractory differentiated thyroid cancer and metastatic medullary carcinoma of the thyroid with functional imaging correlation. Clinical Cancer Research 16 5260-5268. (https:// doi.org/10.1158/1078-0432.CCR-10-0994)

Carter MT, Yome JL, Marcil MN, Martin CA, Vanhorne JB \& Mulligan LM 2001 Conservation of RET proto-oncogene splicing variants and implications for RET isoform function. Cytogenetics and Cell Genetics 95 169-176. (https://doi.org/10.1159/000059341)

Cassinelli G, Favini E, Degl'Innocenti D, Salvi A, De Petro G, Pierotti MA, Zunino F, Borrello MG \& Lanzi C 2009 RET/PTC1driven neoplastic transformation and proinvasive phenotype of human thyrocytes involve Met induction and beta-catenin nuclear translocation. Neoplasia 11 10-21. (https://doi.org/10.1593/ neo.08916)

Castinetti F, Waguespack SG, Machens A, Uchino S, Hasse-Lazar K, Sanso G, Else T, Dvorakova S, Qi XP, Elisei R, et al. 2019 Natural history, treatment, and long-term follow up of patients with multiple endocrine neoplasia type $2 \mathrm{~B}$ : an international, multicentre, retrospective study. Lancet: Diabetes and Endocrinology 7 213-220. (https://doi.org/10.1016/S2213-8587(18)30336-X)

Castroneves LA, Coura Filho G, de Freitas RMC, Salles R, Moyses RA, Lopez RVM, Pereira MAA, Tavares MR, Jorge AAL, Buchpiguel CA, et al. 2018 Comparison of 68Ga PET/CT to other imaging studies in medullary thyroid cancer: superiority in detecting bone metastases. Journal of Clinical Endocrinology and Metabolism 103 3250-3259. (https://doi.org/10.1210/jc.2018-00193)

Ceolin L, Siqueira DR, Ferreira CV, Romitti M, Maia SC, Leiria L, Crispim D, Ashton-Prolla P \& Maia AL 2012a Additive effect of RET polymorphisms on sporadic medullary thyroid carcinoma susceptibility and tumor aggressiveness. European Journal of Endocrinology 166 847-854. (https://doi.org/10.1530/EJE-11-1060)

Ceolin L, Siqueira DR, Romitti M, Ferreira CV \& Maia AL 2012b Molecular basis of medullary thyroid carcinoma: the role of RET polymorphisms. International Journal of Molecular Sciences $\mathbf{1 3}$ 221-239. (https://doi.org/10.3390/ijms13010221)

Ceolin L, Romitti M, Siqueira DR, Vaz Ferreira C, Oliboni Scapineli J, Assis-Brazil B, Vieira Maximiano R, Dias Amarante T, de Souza Nunes MC, Weber G, et al. 2016 Effect of 3'UTR RET variants on RET mRNA secondary structure and disease presentation in medullary thyroid carcinoma. PLOS ONE 11 e0147840. (https://doi.org/10.1371/ journal.pone.0147840)

Ceolin L, Goularte APP, Ferreira CV, Romitti M \& Maia AL 2018 Global DNA methylation profile in medullary thyroid cancer patients. Experimental and Molecular Pathology 105 110-114. (https://doi. org/10.1016/j.yexmp.2018.06.003)

Choi JB, Lee SG, Kim MJ, Kim TH, Ban EJ, Lee CR, Lee J, Kang SW, Jeong JJ, Nam KH, et al. 2018 Dynamic risk stratification in medullary thyroid carcinoma: single institution experiences. Medicine 97 e9686. (https://doi.org/10.1097/MD.0000000000009686)

Chougnet CN, Borget I, Leboulleux S, de la Fouchardiere C, Bonichon F, Criniere L, Niccoli P, Bardet S, Schneegans O, Zanetta S, et al. 2015 Vandetanib for the treatment of advanced medullary thyroid cancer outside a clinical trial: results from a French cohort. Thyroid $\mathbf{2 5}$ 386-391. (https://doi.org/10.1089/thy.2014.0361)

Ciampi R, Mian C, Fugazzola L, Cosci B, Romei C, Barollo S, Cirello V, Bottici V, Marconcini G, Rosa PM, et al. 2013 Evidence of a low prevalence of RAS mutations in a large medullary thyroid cancer series. Thyroid 23 50-57. (https://doi.org/10.1089/thy.2012.0207)

Cohen EE, Rosen LS, Vokes EE, Kies MS, Forastiere AA, Worden FP, Kane MA, Sherman E, Kim S, Bycott P, et al. 2008 Axitinib is an active treatment for all histologic subtypes of advanced thyroid cancer: results from a phase II study. Journal of Clinical Oncology 26 4708-4713. (https://doi.org/10.1200/JCO.2007.15.9566)

Cooper E \& Spaulding SW 1984 Histone and high mobility group protein phosphorylation in the thyroid: regulation by cyclic nucleotides. Endocrinology 115 2324-2331. (https://doi.org/10.1210/ endo-115-6-2324)

Corso S, Migliore C, Ghiso E, De Rosa G, Comoglio PM \& Giordano S 2008 Silencing the MET oncogene leads to regression of experimental tumors and metastases. Oncogene 27 684-693. (https:// doi.org/10.1038/sj.onc.1210697)

Cox TM, Fagan EA, Hillyard CJ, Allison DJ \& Chadwick VS 1979 Role of calcitonin in diarrhoea associated with medullary carcinoma of the thyroid. Gut 20 629-633. (https://doi.org/10.1136/gut.20.7.629)

Da Silva AM, Maciel RM, Da Silva MR, Toledo SR, De Carvalho MB \& Cerutti JM 2003 A novel germ-line point mutation in RET exon 8 (Gly(533)Cys) in a large kindred with familial medullary thyroid carcinoma. Journal of Clinical Endocrinology and Metabolism $\mathbf{8 8}$ 5438-5443. (https://doi.org/10.1210/jc.2003-030997)

de Castroneves LA, Negrao MV, de Freitas RM, Papadia C, Lima Jr JV, Fukushima JT, Simao EF, Kulcsar MA, Tavares MR, Jorge AA, et al. 2016 Sorafenib for the treatment of progressive metastatic medullary thyroid cancer: efficacy and safety analysis. Thyroid 26 414-419. (https://doi.org/10.1089/thy.2015.0334)

de Groot JW, Zonnenberg BA, van Ufford-Mannesse PQ, de Vries MM, Links TP, Lips CJ \& Voest EE 2007 A phase II trial of imatinib therapy for metastatic medullary thyroid carcinoma. Journal of Clinical Endocrinology and Metabolism 92 3466-3469. (https://doi. org/10.1210/jc.2007-0649)

Decker RA, Peacock ML \& Watson P 1998 Hirschsprung disease in MEN 2A: increased spectrum of RET exon 10 genotypes and strong genotype-phenotype correlation. Human Molecular Genetics 7 129-134. (https://doi.org/10.1093/hmg/7.1.129)

Drosten M, Hilken G, Bockmann M, Rodicker F, Mise N, Cranston AN, Dahmen U, Ponder BA \& Putzer BM 2004 Role of MEN2A-derived RET in maintenance and proliferation of medullary thyroid carcinoma. Journal of the National Cancer Institute 96 1231-1239. (https://doi.org/10.1093/jnci/djh226)

Dvorakova S, Vaclavikova E, Sykorova V, Vcelak J, Novak Z, Duskova J, Ryska A, Laco J, Cap J, Kodetova D, et al. 2008 Somatic mutations in the RET proto-oncogene in sporadic medullary thyroid carcinomas. Molecular and Cellular Endocrinology 284 21-27. (https://doi. org/10.1016/j.mce.2007.12.016)

Elisei R, Cosci B, Romei C, Bottici V, Renzini G, Molinaro E, Agate L, Vivaldi A, Faviana P, Basolo F, et al. 2008 Prognostic significance of https://erc.bioscientifica.com

https://doi.org/10.1530/ERC-18-0574 (c) 2019 Society for Endocrinology Published by Bioscientifica Ltd. Printed in Great Britain 
somatic RET oncogene mutations in sporadic medullary thyroid cancer: a 10-year follow-up study. Journal of Clinical Endocrinology and Metabolism 93 682-687. (https://doi.org/10.1210/jc.2007-1714)

Elisei R, Romei C, Renzini G, Bottici V, Cosci B, Molinaro E, Agate L, Cappagli V, Miccoli P, Berti P, et al. 2012 The timing of total thyroidectomy in RET gene mutation carriers could be personalized and safely planned on the basis of serum calcitonin: 18 years experience at one single center. Journal of Clinical Endocrinology and Metabolism 97 426-435. (https://doi.org/10.1210/jc.2011-2046)

Elisei R, Lorusso L, Romei C, Bottici V, Mazzeo S, Giani C, Fiore E, Torregrossa L, Insilla AC, Basolo F, et al. 2013a Medullary thyroid cancer secreting carbohydrate antigen 19-9 (Ca 19-9): a fatal case report. Journal of Clinical Endocrinology and Metabolism 98 3550-3554. (https://doi.org/10.1210/jc.2013-1940)

Elisei R, Schlumberger MJ, Muller SP, Schoffski P, Brose MS, Shah MH, Licitra L, Jarzab B, Medvedev V, Kreissl MC, et al. 2013b Cabozantinib in progressive medullary thyroid cancer. Journal of Clinical Oncology 31 3639-3646.

Elisei R, Lorusso L, Piaggi P, Torregrossa L, Pellegrini G, Molinaro E, Agate L, Bottici V, Pani F, Cacciato Insilla A, et al. 2015 Elevated level of serum carbohydrate antigen 19.9 as predictor of mortality in patients with advanced medullary thyroid cancer. European Journal of Endocrinology 173 297-304. (https://doi.org/10.1530/EJE-15-0304)

Emens LA, Ascierto PA, Darcy PK, Demaria S, Eggermont AMM, Redmond WL, Seliger B \& Marincola FM 2017 Cancer immunotherapy: opportunities and challenges in the rapidly evolving clinical landscape. European Journal of Cancer 81 116-129. (https://doi.org/10.1016/j.ejca.2017.01.035)

Eng C, Mulligan LM, Smith DP, Healey CS, Frilling A, Raue F, Neumann HP, Pfragner R, Behmel A \& Lorenzo MJ 1995 Mutation of the RET protooncogene in sporadic medullary thyroid carcinoma. Genes, Chromosomes and Cancer 12 209-212. (https://doi. org/10.1002/gcc.2870120308)

Eng C, Clayton D, Schuffenecker I, Lenoir G, Cote G, Gagel RF, van Amstel HK, Lips CJ, Nishisho I, Takai SI 1996a The relationship between specific RET proto-oncogene mutations and disease phenotype in multiple endocrine neoplasia type 2 . International RET mutation consortium analysis. JAMA 276 1575-1579. (https://doi. org/10.1001/jama.276.19.1575)

Eng C, Mulligan LM, Healey CS, Houghton C, Frilling A, Raue F, Thomas GA \& Ponder BA $1996 b$ Heterogeneous mutation of the RET proto-oncogene in subpopulations of medullary thyroid carcinoma. Cancer Research 56 2167-2170.

Farooki A, Leung V, Tala H \& Tuttle RM 2012 Skeletal-related events due to bone metastases from differentiated thyroid cancer. Journal of Clinical Endocrinology and Metabolism 97 2433-2439. (https://doi. org/10.1210/jc.2012-1169)

Fernandez RM, Pecina A, Antinolo G, Navarro E \& Borrego S 2006 Analysis of RET polymorphisms and haplotypes in the context of sporadic medullary thyroid carcinoma. Thyroid 16 411-417. (https:// doi.org/10.1089/thy.2006.16.411)

Fernandez-Medarde A \& Santos E 2011 Ras in cancer and developmental diseases. Genes and Cancer 2 344-358. (https://doi. org/10.1177/1947601911411084)

Fox E, Widemann BC, Chuk MK, Marcus L, Aikin A, Whitcomb PO, Merino MJ, Lodish M, Dombi E, Steinberg SM, et al. 2013 Vandetanib in children and adolescents with multiple endocrine neoplasia type 2B associated medullary thyroid carcinoma. Clinical Cancer Research 19 4239-4248. (https://doi.org/10.1158/1078-0432. CCR-13-0071)

Frank-Raue K, Rybicki LA, Erlic Z, Schweizer H, Winter A, Milos I, Toledo SP, Toledo RA, Tavares MR, Alevizaki M, et al. 2011 Risk profiles and penetrance estimations in multiple endocrine neoplasia type $2 \mathrm{~A}$ caused by germline RET mutations located in exon 10. Human Mutation 32 51-58. (https://doi.org/10.1002/humu.21385)
Fromigue J, De Baere T, Baudin E, Dromain C, Leboulleux S \& Schlumberger M 2006 Chemoembolization for liver metastases from medullary thyroid carcinoma. Journal of Clinical Endocrinology and Metabolism 91 2496-2499. (https://doi.org/10.1210/jc.2005-2401) Gagel RF, Levy ML, Donovan DT, Alford BR, Wheeler T \& Tschen JA 1989 Multiple endocrine neoplasia type 2a associated with cutaneous lichen amyloidosis. Annals of Internal Medicine $\mathbf{1 1 1}$ 802-806. (https://doi.org/10.7326/0003-4819-111-10-802)

Giraudet AL, Vanel D, Leboulleux S, Auperin A, Dromain C, Chami L, Ny Tovo N, Lumbroso J, Lassau N, Bonniaud G, et al. 2007 Imaging medullary thyroid carcinoma with persistent elevated calcitonin levels. Journal of Clinical Endocrinology and Metabolism 92 4185-4190. (https://doi.org/10.1210/jc.2007-1211)

Girelli ME, Nacamulli D, Pelizzo MR, De Vido D, Mian C, Piccolo M \& Busnardo B 1998 Medullary thyroid carcinoma: clinical features and long-term follow-up of seventy-eight patients treated between 1969 and 1986. Thyroid 8 517-523. (https://doi.org/10.1089/ thy.1998.8.517)

Gonzatti-Haces M, Park M, Dean M, Blair DG \& Vande Woude GF 1986 The human met oncogene is a member of the tyrosine kinase family. Princess Takamatsu Symposia 17 221-232.

Grande E, Kreissl MC, Filetti S, Newbold K, Reinisch W, Robert C, Schlumberger M, Tolstrup LK, Zamorano JL \& Capdevila J 2013 Vandetanib in advanced medullary thyroid cancer: review of adverse event management strategies. Advances in Therapy 30 945-966. (https://doi.org/10.1007/s12325-013-0069-5)

Hadoux J \& Schlumberger 2017 Chemotherapy and tyrosine-kinase inhibitors for medullary thyroid cancer. Best Practice and Research in Clinical Endocrinology and Metabolism 31 335-347.

Hannah-Shmouni F, Stratakis CA \& Koch CA 2016 Flushing in (neuro) endocrinology. Reviews in Endocrine and Metabolic Disorders 17 373-380. (https://doi.org/10.1007/s11154-016-9394-8)

Haugen BR, Alexander EK, Bible KC, Doherty GM, Mandel SJ, Nikiforov YE, Pacini F, Randolph GW, Sawka AM, Schlumberger M, et al. 20162015 American Thyroid Association management guidelines for adult patients with thyroid nodules and differentiated thyroid cancer: the American Thyroid Association Guidelines Task Force on Thyroid Nodules and Differentiated Thyroid Cancer. Thyroid 26 1-133. (https://doi.org/10.1089/thy.2015.0020)

Heilmann AM, Subbiah V, Wang K, Sun JX, Elvin JA, Chmielecki J, Sherman SI, Murthy R, Busaidy NL, Subbiah I, et al. 2016 Comprehensive genomic profiling of clinically advanced medullary thyroid carcinoma. Oncology 90 339-346. (https://doi. org/10.1159/000445978)

Heshmati HM, Gharib H, van Heerden JA \& Sizemore GW 1997 Advances and controversies in the diagnosis and management of medullary thyroid carcinoma. American Journal of Medicine 103 60-69. (https://doi.org/10.1016/S0002-9343(97)00024-7)

Jacinto E, Facchinetti V, Liu D, Soto N, Wei S, Jung SY, Huang Q, Qin J \& Su B 2006 SIN1/MIP1 maintains rictor-mTOR complex integrity and regulates Akt phosphorylation and substrate specificity. Cell $\mathbf{1 2 7}$ 125-137. (https://doi.org/10.1016/j.cell.2006.08.033)

Jarzab B, Szpak-Ulczok S, Wloch J, Czarniecka A \& Krajewska J 2013 Timing and criteria for prophylactic thyroidectomy in asymptomatic RET carriers - the role of Ct serum level. Thyroid Research 6 (Supplement 1) S9. (https://doi.org/10.1186/1756-6614-6-S1-S9)

Johansson E, Andersson L, Ornros J, Carlsson T, Ingeson-Carlsson C, Liang S, Dahlberg J, Jansson S, Parrillo L, Zoppoli P, et al. 2015 Revising the embryonic origin of thyroid C cells in mice and humans. Development 142 3519-3528. (https://doi.org/10.1242/ dev.126581)

Karanikas G, Moameni A, Poetzi C, Zettinig G, Kaserer K, Bieglmayer C, Niederle B, Dudczak R \& Pirich C 2004 Frequency and relevance of elevated calcitonin levels in patients with neoplastic and nonneoplastic thyroid disease and in healthy subjects. Journal of https://erc.bioscientifica.com

https://doi.org/10.1530/ERC-18-0574 (c) 2019 Society for Endocrinology Published by Bioscientifica Ltd. Printed in Great Britain 
Clinical Endocrinology and Metabolism 89 515-519. (https://doi. org/10.1210/jc.2003-030709)

Kasprzak L, Nolet S, Gaboury L, Pavia C, Villabona C, Rivera-Fillat F, Oriola J \& Foulkes WD 2001 Familial medullary thyroid carcinoma and prominent corneal nerves associated with the germline V804M and V778I mutations on the same allele of RET. Journal of Medical Genetics 38 784-787. (https://doi.org/10.1136/jmg.38.11.784)

Kawai K, Iwashita T, Murakami H, Hiraiwa N, Yoshiki A, Kusakabe M, Ono K, Iida K, Nakayama A \& Takahashi M 2000 Tissue-specific carcinogenesis in transgenic mice expressing the RET protooncogene with a multiple endocrine neoplasia type $2 \mathrm{~A}$ mutation. Cancer Research 60 5254-5260.

Kebebew E, Ituarte PH, Siperstein AE, Duh QY \& Clark OH 2000 Medullary thyroid carcinoma: clinical characteristics, treatment, prognostic factors, and a comparison of staging systems. Cancer $\mathbf{8 8}$ 1139-1148. (https://doi.org/10.1002/(sici)1097-

0142(20000301)88:5<1139::aid-cncr26>3.0.co;2-z)

Kebebew E, Greenspan FS, Clark OH, Woeber KA \& Grunwell J 2005 Extent of disease and practice patterns for medullary thyroid cancer. Journal of the American College of Surgeons 200 890-896. (https://doi. org/10.1016/j.jamcollsurg.2004.12.011)

Kihara M, Miyauchi A, Yoshida H, Yamada O, Masuoka H, Yabuta T, Higashiyama T, Fukushima M, Ito Y, Kobayashi K, et al. 2014 Tandem germline RET mutations in a family pathogenetic for multiple endocrine neoplasia $2 \mathrm{~B}$, confirmed by a natural experiment. European Thyroid Journal 3 272-277. (https://doi. org/10.1159/000369134)

Kouvaraki MA, Liakou C, Paraschi A, Dimas K, Patsouris E, TseleniBalafouta S, Rassidakis GZ \& Moraitis D 2011 Activation of mTOR signaling in medullary and aggressive papillary thyroid carcinomas. Surgery 150 1258-1265. (https://doi.org/10.1016/j.surg.2011.09.022)

Krasilnikov MA 2000 Phosphatidylinositol-3 kinase dependent pathways: the role in control of cell growth, survival, and malignant transformation. Biochemistry 65 59-67.

Kuo EJ, Sho S, Li N, Zanocco KA, Yeh MW \& Livhits MJ 2018 Risk factors associated with reoperation and disease-specific mortality in patients with medullary thyroid carcinoma. JAMA Surgery 153 52-59. (https://doi.org/10.1001/jamasurg.2017.3555)

Kwon H, Kim WG, Sung TY, Jeon MJ, Song DE, Lee YM, Yoon JH, Chung KW, Hong SJ, Baek JH, et al. 2016 Changing trends in the clinicopathological features and clinical outcomes of medullary thyroid carcinoma. Journal of Surgical Oncology 113 152-158. (https:// doi.org/10.1002/jso.24126)

Lam ET, Ringel MD, Kloos RT, Prior TW, Knopp MV, Liang J, Sammet S, Hall NC, Wakely Jr PE, Vasko VV, et al. 2010 Phase II clinical trial of sorafenib in metastatic medullary thyroid cancer. Journal of Clinical Oncology 28 2323-2330. (https://doi.org/10.1200/JCO.2009.25.0068)

Leboulleux S, Baudin E, Travagli JP \& Schlumberger M 2004 Medullary thyroid carcinoma. Clinical Endocrinology 61 299-310.

Lemmon MA \& Schlessinger J 2010 Cell signaling by receptor tyrosine kinases. Cell 141 1117-1134. (https://doi.org/10.1016/j. cell.2010.06.011)

Lim SM, Chang H, Yoon MJ, Hong YK, Kim H, Chung WY, Park CS, Nam KH, Kang SW, Kim MK, et al. 2013 A multicenter, phase II trial of everolimus in locally advanced or metastatic thyroid cancer of all histologic subtypes. Annals of Oncology 24 3089-3094. (https://doi. org/10.1093/annonc/mdt379)

Lim H, Devesa SS, Sosa JA, Check D \& Kitahara CM 2017 Trends in thyroid cancer incidence and mortality in the United States, 19742013. JAMA 317 1338-1348. (https://doi.org/10.1001/ jama.2017.2719)

Lindsey SC, Ganly I, Palmer F \& Tuttle RM 2015 Response to initial therapy predicts clinical outcomes in medullary thyroid cancer. Thyroid 25 242-249. (https://doi.org/10.1089/thy.2014.0277)

Liu X, Yao W, Newton RC \& Scherle PA 2008 Targeting the c-MET signaling pathway for cancer therapy. Expert Opinion on
Investigational Drugs 17 997-1011. (https://doi. org/10.1517/13543784.17.7.997)

Liu X, Shen T, Mooers BHM, Hilberg F \& Wu J 2018 Drug resistance profiles of mutations in the RET kinase domain. British Journal of Pharmacology 175 3504-3515. (https://doi.org/10.1111/bph.14395)

Machens A \& Dralle H 2010 Biomarker-based risk stratification for previously untreated medullary thyroid cancer. Journal of Clinical Endocrinology and Metabolism 95 2655-2663. (https://doi. org/10.1210/jc.2009-2368)

Machens A, Niccoli-Sire P, Hoegel J, Frank-Raue K, van Vroonhoven TJ, Roeher HD, Wahl RA, Lamesch P, Raue F, Conte-Devolx B, et al. 2003 Early malignant progression of hereditary medullary thyroid cancer. New England Journal of Medicine 349 1517-1525. (https://doi. org/10.1056/NEJMoa012915)

Machens A, Lorenz K, Weber F \& Dralle H 2018 Genotype-specific progression of hereditary medullary thyroid cancer. Human Mutation 39 860-869. (https://doi.org/10.1002/humu.23430)

Maciel RMB, Camacho CP, Assumpcao LVM, Bufalo NE, Carvalho AL, de Carvalho GA, Castroneves LA, de Castro Jr FM, Ceolin L, Cerutti JM, et al. 2019 Genotype and phenotype landscape of MEN2 in 554 medullary thyroid cancer patients: the BrasMEN study. Endocrine Connections 8 289-298. (https://doi.org/10.1530/EC-18-0506)

Mahler C, Verhelst J, de Longueville M \& Harris A 1990 Long-term treatment of metastatic medullary thyroid carcinoma with the somatostatin analogue octreotide. Clinical Endocrinology 33 261-269. (https://doi.org/10.1111/j.1365-2265.1990.tb00490.x)

Maia AL, Siqueira DR, Kulcsar MA, Tincani AJ, Mazeto GM \& Maciel LM 2014 Diagnosis, treatment, and follow-up of medullary thyroid carcinoma: recommendations by the Thyroid Department of the Brazilian Society of Endocrinology and Metabolism. Arquivos Brasileiros de Endocrinologia e Metabologia 58 667-700. (https://doi. org/10.1590/0004-2730000003427)

Maia AL, Wajner SM \& Vargas CV 2017 Advances and controversies in the management of medullary thyroid carcinoma. Current Opinion in Oncology 29 25-32. (https://doi.org/10.1097/ CCO.0000000000000340)

Makri A, Akshintala S, Derse-Anthony C, Widemann B, Stratakis CA, Glod J \& Lodish M 2018 Multiple endocrine neoplasia type 2B presents early in childhood but often is undiagnosed for years. Journal of Pediatrics 203 447-449. (https://doi.org/10.1016/j. jpeds.2018.08.022)

Martin J, Masri J, Bernath A, Nishimura RN \& Gera J 2008 Hsp70 associates with Rictor and is required for mTORC2 formation and activity. Biochemical and Biophysical Research Communications $\mathbf{3 7 2}$ 578-583. (https://doi.org/10.1016/j.bbrc.2008.05.086)

Martinez SR, Beal SH, Chen A, Chen SL \& Schneider PD 2010 Adjuvant external beam radiation for medullary thyroid carcinoma. Journal of Surgical Oncology 102 175-178. (https://doi.org/10.1002/jso.21557)

Massaro F, Dolcino M, Degrandi R, Ferone D, Mussap M, Minuto F \& Giusti M 2009 Calcitonin assay in wash-out fluid after fine-needle aspiration biopsy in patients with a thyroid nodule and border-line value of the hormone. Journal of Endocrinological Investigation 32 308-312. (https://doi.org/10.1007/BF03345717)

Massicotte MH, Borget I, Broutin S, Baracos VE, Leboulleux S, Baudin E, Paci A, Deroussent A, Schlumberger M \& Antoun S 2013 Body composition variation and impact of low skeletal muscle mass in patients with advanced medullary thyroid carcinoma treated with vandetanib: results from a placebo-controlled study. Journal of Clinical Endocrinology and Metabolism 98 2401-2408. (https://doi. org/10.1210/jc.2013-1115)

Mathiesen JS, Habra MA, Bassett JHD, Choudhury SM, Balasubramanian SP, Howlett TA, Robinson BG, GimenezRoqueplo AP, Castinetti F, Vestergaard P, et al. 2017 Risk profile of the RET A883F germline mutation: an international collaborative study. Journal of Clinical Endocrinology and Metabolism 102 2069-2074. (https://doi.org/10.1210/jc.2016-3640) https://erc.bioscientifica.com

https://doi.org/10.1530/ERC-18-0574 (c) 2019 Society for Endocrinology Published by Bioscientifica Ltd. Printed in Great Britain 
Meijer JA, le Cessie S, van den Hout WB, Kievit J, Schoones JW, Romijn JA \& Smit JW 2010 Calcitonin and carcinoembryonic antigen doubling times as prognostic factors in medullary thyroid carcinoma: a structured meta-analysis. Clinical Endocrinology $\mathbf{7 2}$ 534-542. (https://doi.org/10.1111/j.1365-2265.2009.03666.x)

Menko FH, van der Luijt RB, de Valk IA, Toorians AW, Sepers JM, van Diest PJ \& Lips CJ 2002 Atypical MEN type 2B associated with two germline RET mutations on the same allele not involving codon 918. Journal of Clinical Endocrinology and Metabolism 87 393-397. (https://doi.org/10.1210/jcem.87.1.8136)

Meric-Bernstam F \& Gonzalez-Angulo AM 2009 Targeting the mTOR signaling network for cancer therapy. Journal of Clinical Oncology 27 2278-2287. (https://doi.org/10.1200/JCO.2008.20.0766)

Mian C, Perrino M, Colombo C, Cavedon E, Pennelli G, Ferrero S, De Leo S, Sarais C, Cacciatore C, Manfredi GI, et al. 2014 Refining calcium test for the diagnosis of medullary thyroid cancer: cutoffs, procedures, and safety. Journal of Clinical Endocrinology and Metabolism 99 1656-1664. (https://doi.org/10.1210/jc.2013-4088)

Michiels FM, Chappuis S, Caillou B, Pasini A, Talbot M, Monier R, Lenoir GM, Feunteun J \& Billaud M 1997 Development of medullary thyroid carcinoma in transgenic mice expressing the RET protooncogene altered by a multiple endocrine neoplasia type $2 \mathrm{~A}$ mutation. PNAS 94 3330-3335. (https://doi.org/10.1073/ pnas.94.7.3330)

Milman S, Whitney KD \& Fleischer N 2011 Metastatic medullary thyroid cancer presenting with elevated levels of CA 19-9 and CA 125. Thyroid 21 913-916. (https://doi.org/10.1089/thy.2010.0425)

Milman S, Arnold JL, Price M, Negassa A, Surks MI, Fleischer N \& Whitney KD 2015 Medullary thyroid cancer that stains negative for Ca 19-9 has decreased metastatic potential. Endocrine Practice 21 590-594. (https://doi.org/10.4158/EP14357.OR)

Modigliani E, Cohen R, Campos JM, Conte-Devolx B, Maes B, Boneu A, Schlumberger, Bigorgne JC, Dumontier P, Leclerc L, et al. 1998 Prognostic factors for survival and for biochemical cure in medullary thyroid carcinoma: results in 899 patients. The GETC Study Group. Groupe d'etude des tumeurs a calcitonine. Clinical Endocrinology $\mathbf{4 8}$ 265-273.

Moura MM, Cavaco BM, Pinto AE \& Leite V 2011 High prevalence of RAS mutations in RET-negative sporadic medullary thyroid carcinomas. Journal of Clinical Endocrinology and Metabolism 96 E863-E868. (https://doi.org/10.1210/jc.2010-1921)

Moura MM, Cavaco BM \& Leite V 2015 RAS proto-oncogene in medullary thyroid carcinoma. Endocrine-Related Cancer 22 R235-R252. (https://doi.org/10.1530/ERC-15-0070)

Mulligan LM 2014 RET revisited: expanding the oncogenic portfolio. Nature Reviews: Cancer 14 173-186. (https://doi.org/10.1038/nrc3680)

Mulligan LM 201865 YEARS OF THE DOUBLE HELIX: Exploiting insights on the RET receptor for personalized cancer medicine. Endocrine-Related Cancer 25 T189-T200. (https://doi.org/10.1530/ ERC-18-0141)

Myers SM, Eng C, Ponder BA \& Mulligan LM 1995 Characterization of RET proto-oncogene 3' splicing variants and polyadenylation sites: a novel C-terminus for RET. Oncogene 11 2039-2045.

Naoum GE, Morkos M, Kim B \& Arafat W 2018 Novel targeted therapies and immunotherapy for advanced thyroid cancers. Molecular Cancer 17 51. (https://doi.org/10.1186/s12943-018-0786-0)

Nella AA, Lodish MB, Fox E, Balis FM, Quezado MM, Whitcomb PO, Derdak J, Kebebew E, Widemann BC \& Stratakis CA 2014 Vandetanib successfully controls medullary thyroid cancer-related Cushing syndrome in an adolescent patient. Journal of Clinical Endocrinology and Metabolism 99 3055-3059. (https://doi. org/10.1210/jc.2013-4340)

Nikiforova MN, Wald AI, Roy S, Durso MB \& Nikiforov YE 2013 Targeted next-generation sequencing panel (ThyroSeq) for detection of mutations in thyroid cancer. Journal of Clinical Endocrinology and Metabolism 98 E1852-E1860. (https://doi.org/10.1210/jc.2013-2292)
Nilsson M \& Williams D 2016 On the origin of cells and derivation of thyroid cancer: C cell story revisited. European Thyroid Journal $\mathbf{5}$ 79-93. (https://doi.org/10.1159/000447333)

Nocera M, Baudin E, Pellegriti G, Cailleux AF, Mechelany-Corone C \& Schlumberger M 2000 Treatment of advanced medullary thyroid cancer with an alternating combination of doxorubicin-streptozocin and 5 FU-dacarbazine. Groupe d'Etude des Tumeurs à Calcitonine (GETC). British Journal of Cancer 83 715-718. (https://doi. org/10.1054/bjoc.2000.1314)

Papotti M, Olivero M, Volante M, Negro F, Prat M, Comoglio PM \& DiRenzo MF 2000 Expression of hepatocyte growth factor (HGF) and its receptor (MET) in medullary carcinoma of the thyroid. Endocrine Pathology 11 19-30. (https://doi.org/10.1385/EP:11:1:19)

Park M, Gonzatti-Haces M, Dean M, Blair DG, Testa JR, Bennett DD, Copeland T, Oroszlan S \& Vande Woude G 1986 The met oncogene: a new member of the tyrosine kinase family and a marker for cystic fibrosis. Cold Spring Harbor Symposia on Quantitative Biology $\mathbf{5 1}$ 967-975. (https://doi.org/10.1101/SQB.1986.051.01.110)

Pecce V, Sponziello M, Damante G, Rosignolo F, Durante C, Lamartina L, Grani G, Russo D, di Gioia CR, Filetti S, et al. 2018 A synonymous RET substitution enhances the oncogenic effect of an in-cis missense mutation by increasing constitutive splicing efficiency. PLoS Genetics 14 e1007678. (https://doi.org/10.1371/journal.pgen.1007678)

Pelizzo MR, Boschin IM, Bernante P, Toniato A, Piotto A, Pagetta C, Nibale O, Rampin L, Muzzio PC \& Rubello D 2007 Natural history, diagnosis, treatment and outcome of medullary thyroid cancer: 37 years experience on 157 patients. European Journal of Surgical Oncology 33 493-497. (https://doi.org/10.1016/j.ejso.2006.10.021)

Punales MK, Graf H, Gross JL \& Maia AL 2003 RET codon 634 mutations in multiple endocrine neoplasia type 2: variable clinical features and clinical outcome. Journal of Clinical Endocrinology and Metabolism 88 2644-2649. (https://doi.org/10.1210/jc.2002-021422)

Punales MK, da Rocha AP, Meotti C, Gross JL \& Maia AL 2008 Clinical and oncological features of children and young adults with multiple endocrine neoplasia type 2A. Thyroid 18 1261-1268. (https://doi. org/10.1089/thy.2007.0414)

Rambaud JC, Jian R, Flourie B, Hautefeuille M, Salmeron M, Thuillier F, Ruskone A, Florent C, Chaoui F \& Bernier JJ 1988 Pathophysiological study of diarrhoea in a patient with medullary thyroid carcinoma. Evidence against a secretory mechanism and for the role of shortened colonic transit time. Gut 29 537-543. (https://doi. org/10.1136/gut.29.4.537)

Randle RW, Balentine CJ, Leverson GE, Havlena JA, Sippel RS, Schneider DF \& Pitt SC 2017 Trends in the presentation, treatment, and survival of patients with medullary thyroid cancer over the past 30 years. Surgery 161 137-146. (https://doi.org/10.1016/j. surg.2016.04.053)

Raue F \& Frank-Raue K 2009 Genotype-phenotype relationship in multiple endocrine neoplasia type 2. Implications for clinical management. Hormones 8 23-28. (https://doi.org/10.14310/ horm.2002.1218)

Resteghini C, Cavalieri S, Galbiati D, Granata R, Alfieri S, Bergamini C, Bossi P, Licitra L \& Locati LD 2017 Management of tyrosine kinase inhibitors (TKI) side effects in differentiated and medullary thyroid cancer patients. Best Practice and Research: Clinical Endocrinology and Metabolism 31 349-361. (https://doi.org/10.1016/j.beem.2017.04.012)

Ricarte-Filho JC, Ryder M, Chitale DA, Rivera M, Heguy A, Ladanyi M, Janakiraman M, Solit D, Knauf JA, Tuttle RM, et al. 2009 Mutational profile of advanced primary and metastatic radioactive iodinerefractory thyroid cancers reveals distinct pathogenetic roles for BRAF, PIK3CA, and AKT1. Cancer Research 69 4885-4893. (https:// doi.org/10.1158/0008-5472.CAN-09-0727)

Roman S, Lin R \& Sosa JA 2006 Prognosis of medullary thyroid carcinoma: demographic, clinical, and pathologic predictors of survival in 1252 cases. Cancer 107 2134-2142. (https://doi. org/10.1002/cncr.22244) https://erc.bioscientifica.com

https://doi.org/10.1530/ERC-18-0574 (c) 2019 Society for Endocrinology Published by Bioscientifica Ltd. Printed in Great Britain 
Romei C, Ciampi R \& Elisei R 2016 A comprehensive overview of the role of the RET proto-oncogene in thyroid carcinoma. Nature Reviews: Endocrinology 12 192-202. (https://doi.org/10.1038/ nrendo.2016.11)

Romei C, Ciampi R, Casella F, Tacito A, Torregrossa L, Ugolini C, Basolo F, Materazzi G, Vitti P \& Elisei R 2018 RET mutation heterogeneity in primary advanced medullary thyroid cancers and their metastases. Oncotarget 9 9875-9884. (https://doi.org/10.18632/ oncotarget.23986)

Romero-Lluch AR, Cuenca-Cuenca JI, Guerrero-Vazquez R, MartinezOrtega AJ, Tirado-Hospital JL, Borrego-Dorado I \& NavarroGonzález E 2017 Diagnostic utility of PET/CT with 18F-DOPA and 18F-FDG in persistent or recurrent medullary thyroid carcinoma: the importance of calcitonin and carcinoembryonic antigen cutoff. European Journal of Nuclear Medicine and Molecular Imaging 44 2004-2013. (https://doi.org/10.1007/s00259-017-3759-4)

Rosario PW \& Calsolari MR 2016 Usefulness of serum calcitonin in patients without a suspicious history of medullary thyroid carcinoma and with thyroid nodules without an indication for fineneedle aspiration or with benign cytology. Hormone and Metabolic Research 48 372-276. (https://doi.org/10.1055/s-0042-107246)

Santarpia L, Myers JN, Sherman SI, Trimarchi F, Clayman GL \& El-Naggar AK 2010 Genetic alterations in the RAS/RAF/mitogenactivated protein kinase and phosphatidylinositol 3-kinase/Akt signaling pathways in the follicular variant of papillary thyroid carcinoma. Cancer 116 2974-2983. (https://doi.org/10.1002/ cncr.25061)

Sarika HL, Papathoma A, Garofalaki M, Saltiki K, Pappa T, PazaitouPanayiotou K, Anastasiou E \& Alevizaki M 2015 Genetic screening of patients with medullary thyroid cancer in a referral center in Greece during the past two decades. European Journal of Endocrinology 172 501-509. (https://doi.org/10.1530/EJE-14-0817)

Scapineli JO, Ceolin L, Punales MK, Dora JM \& Maia AL 2016 MEN 2A-related cutaneous lichen amyloidosis: report of three kindred and systematic literature review of clinical, biochemical and molecular characteristics. Familial Cancer 15 625-633. (https://doi.org/10.1007/ s10689-016-9892-6)

Scheffel RS, Dora JM, Siqueira DR, Burttet LM, Cerski MR \& Maia AL 2013 Toxic cardiomyopathy leading to fatal acute cardiac failure related to vandetanib: a case report with histopathological analysis. European Journal of Endocrinology 168 K51-K54. (https://doi. org/10.1530/EJE-13-0015)

Schlumberger MJ, Elisei R, Bastholt L, Wirth LJ, Martins RG, Locati LD, Jarzab B, Pacini F, Daumerie C, Droz JP, et al. 2009 Phase II study of safety and efficacy of motesanib in patients with progressive or symptomatic, advanced or metastatic medullary thyroid cancer. Journal of Clinical Oncology 27 3794-3801.

Schlumberger, Bastholt L, Dralle H, Jarzab B, Pacini F, Smit JW \& European Thyroid Association Task Force 20122012 European Thyroid Association guidelines for metastatic medullary thyroid cancer. European Thyroid Journal 1 5-14.

Schlumberger M, Jarzab B, Cabanillas ME, Robinson B, Pacini F, Ball DW, McCaffrey J, Newbold K, Allison R, Martins RG, et al. 2016 A phase II trial of the multitargeted tyrosine kinase inhibitor lenvatinib (E7080) in advanced medullary thyroid cancer. Clinical Cancer Research 22 44-53. (https://doi.org/10.1158/1078-0432.CCR15-1127)

Schlumberger M, Elisei R, Muller S, Schoffski P, Brose M, Shah M, Licitra L, Krajewska J, Kreissl MC, Niederle B, et al. 2017 Overall survival analysis of EXAM, a phase III trial of cabozantinib in patients with radiographically progressive medullary thyroid carcinoma. Annals of Oncology 28 2813-2819. (https://doi. org/10.1093/annonc/mdx479)

Schmid KW 2015 Histopathology of C cells and medullary thyroid carcinoma. Recent Results in Cancer Research 204 41-60. (https://doi. org/10.1007/978-3-319-22542-5_2)
Schneider TC, de Wit D, Links TP, van Erp NP, van der Hoeven JJ, Gelderblom H, van Wezel T, van Eijk R, Morreau H, Guchelaar HJ, et al. 2015 Beneficial effects of the mTOR inhibitor everolimus in patients with advanced medullary thyroid carcinoma: subgroup results of a Phase II trial. International Journal of Endocrinology 2015 348124. (https://doi.org/10.1155/2015/348124)

Schwartz DL, Rana V, Shaw S, Yazbeck C, Ang KK, Morrison WH, Rosenthal DI, Hoff A, Evans DB, Clayman GL, et al. 2008 Postoperative radiotherapy for advanced medullary thyroid cancer - local disease control in the modern era. Head and Neck 30 883-888. (https://doi.org/10.1002/hed.20791)

Scollo C, Baudin E, Travagli JP, Caillou B, Bellon N, Leboulleux S \& Schlumberger M 2003 Rationale for central and bilateral lymph node dissection in sporadic and hereditary medullary thyroid cancer. Journal of Clinical Endocrinology and Metabolism 88 2070-2075. (https://doi.org/10.1210/jc.2002-021713)

Sekulic A, Hudson CC, Homme JL, Yin P, Otterness DM, Karnitz LM \& Abraham RT 2000 A direct linkage between the phosphoinositide 3-kinase-AKT signaling pathway and the mammalian target of rapamycin in mitogen-stimulated and transformed cells. Cancer Research 60 3504-3513.

Sherman SI, Clary DO, Elisei R, Schlumberger MJ, Cohen EE, Schoffski P, Wirth LJ, Mangeshkar M, Aftab DT \& Brose MS 2016 Correlative analyses of RET and RAS mutations in a phase 3 trial of cabozantinib in patients with progressive, metastatic medullary thyroid cancer. Cancer 122 3856-3864.

Shimizu K, Goldfarb M, Suard Y, Perucho M, Li Y, Kamata T, Feramisco J, Stavnezer E, Fogh J \& Wigler MH 1983 Three human transforming genes are related to the viral ras oncogenes. PNAS 80 2112-2116. (https://doi.org/10.1073/pnas.80.8.2112)

Skinner MA, Moley JA, Dilley WG, Owzar K, Debenedetti MK \& Wells Jr SA 2005 Prophylactic thyroidectomy in multiple endocrine neoplasia type 2A. New England Journal of Medicine 353 1105-1113. (https:// doi.org/10.1056/NEJMoa043999)

Smith-Hicks CL, Sizer KC, Powers JF, Tischler AS \& Costantini F 2000 C-cell hyperplasia, pheochromocytoma and sympathoadrenal malformation in a mouse model of multiple endocrine neoplasia type 2B. EMBO Journal 19 612-622. (https://doi.org/10.1093/ emboj/19.4.612)

Sosa JA, Duh QY \& Doherty G 2017 Striving for clarity About the best approach to thyroid cancer screening and treatment: is the pendulum swinging too far? JAMA Surgery 152 721-722. (https://doi. org/10.1001/jamasurg.2017.1338)

Sponziello M, Durante C, Boichard A, Dima M, Puppin C, Verrienti A, Tamburrano G, Di Rocco G, Redler A, Lacroix L, et al. 2014 Epigenetic-related gene expression profile in medullary thyroid cancer revealed the overexpression of the histone methyltransferases EZH2 and SMYD3 in aggressive tumours. Molecular and Cellular Endocrinology 392 8-13. (https://doi.org/10.1016/j.mce.2014.04.016)

Sponziello M, Benvenuti S, Gentile A, Pecce V, Rosignolo F, Virzi AR, Milan M, Comoglio PM, Londin E, Fortina P, et al. 2018 Whole exome sequencing identifies a germline MET mutation in two siblings with hereditary wild-type RET medullary thyroid cancer. Human Mutation 39 371-377. (https://doi.org/10.1002/humu.23378)

Subbiah V, Gainor JF, Rahal R, Brubaker JD, Kim JL, Maynard M, Hu W, Cao Q, Sheets MP, Wilson D, et al. 2018a Precision targeted therapy with BLU-667 for RET-driven cancers. Cancer Discovery 8 836-849. (https://doi.org/10.1158/2159-8290.CD-18-0338)

Subbiah V, Velcheti V, Tuch BB, Ebata K, Busaidy NL, Cabanillas ME, Wirth LJ, Stock S, Smith S, Lauriault V, et al. $2018 b$ Selective RET kinase inhibition for patients with RET-altered cancers. Annals of Oncology 29 1869-1876. (https://doi.org/10.1093/annonc/mdy137)

Sun Y, Du F, Gao M, Ji Q, Li Z, Zhang Y, Guo Z, Wang J, Chen X, Wang J, et al. 2018 Anlotinib for the treatment of patients with locally advanced or metastatic medullary thyroid cancer. Thyroid $\mathbf{2 8}$ 1455-1461. (https://doi.org/10.1089/thy.2018.0022) 
Tahira T, Ishizaka Y, Itoh F, Sugimura T \& Nagao M 1990 Characterization of RET proto-oncogene mRNAs encoding two isoforms of the protein product in a human neuroblastoma cell line. Oncogene 5 97-102.

Takahashi M, Ritz J \& Cooper GM 1985 Activation of a novel human transforming gene, ret, by DNA rearrangement. Cell 42 581-588. (https://doi.org/10.1016/0092-8674(85)90115-1)

Takahashi M, Buma Y, Iwamoto T, Inaguma Y, Ikeda H \& Hiai H 1988 Cloning and expression of the RET proto-oncogene encoding a tyrosine kinase with two potential transmembrane domains. Oncogene 3 571-578.

Takahashi M, Buma Y \& Taniguchi M 1991 Identification of the RET proto-oncogene products in neuroblastoma and leukemia cells. Oncogene 6 297-301.

Takahashi M, Asai N, Iwashita T, Isomura T, Miyazaki K \& Matsuyama M 1993 Characterization of the RET proto-oncogene products expressed in mouse L cells. Oncogene 8 2925-2929.

Tamburrino A, Molinolo AA, Salerno P, Chernock RD, Raffeld M, Xi L, Gutkind JS, Moley JF, Wells Jr SA \& Santoro M 2012 Activation of the mTOR pathway in primary medullary thyroid carcinoma and lymph node metastases. Clinical Cancer Research 18 3532-3540. (https://doi.org/10.1158/1078-0432.CCR-11-2700)

Tormey WP, Byrne B, Hill AD, Sherlock M \& Thompson CJ 2017 Should serum calcitonin be routinely measured in patients presenting with thyroid nodule? Minerva Endocrinologica 42 306-310. (https://doi. org/10.23736/S0391-1977.17.02566-4)

Trimboli P, Rossi F, Baldelli R, Laurenti O, Nigri G, Ventura C, Appetecchia M, Attanasio D, Romanelli F, Guidobaldi L, et al. 2012 Measuring calcitonin in washout of the needle in patients undergoing fine needle aspiration with suspicious medullary thyroid cancer. Diagnostic Cytopathology 40 394-398. (https://doi. org/10.1002/dc.21731)

Trimboli P, Cremonini N, Ceriani L, Saggiorato E, Guidobaldi L, Romanelli F, Ventura C, Laurenti O, Messuti I, Solaroli E, et al. 2014 Calcitonin measurement in aspiration needle washout fluids has higher sensitivity than cytology in detecting medullary thyroid cancer: a retrospective multicentre study. Clinical Endocrinology $\mathbf{8 0}$ 135-140. (https://doi.org/10.1111/cen.12234)

Trimboli P, Castellana M, Virili C, Giorgino F \& Giovanella L 2018 Efficacy of vandetanib in treating locally advanced or metastatic medullary thyroid carcinoma according to RECIST criteria: a systematic review and meta-analysis. Frontiers in Endocrinology 9224. (https://doi.org/10.3389/fendo.2018.00224)

Turk Y, Makay O, Ozdemir M, Ertunc G, Demir B, Icoz G, Akyildiz M \& Yilmaz M 2017 Routine calcitonin measurement in nodular thyroid disease management: is it worthwhile? Annals of Surgical Treatment and Research 92 173-178. (https://doi.org/10.4174/astr.2017.92.4.173)

Tuttle RM, Haddad RI, Ball DW, Byrd D, Dickson P, Duh QY, Ehya H, Haymart M, Hoh C, Hunt JP, et al. 2014 Thyroid carcinoma, version 2.2014. Journal of the National Comprehensive Cancer Network 12 1671-1680; quiz 1680.
Valle LA \& Kloos RT 2011 The prevalence of occult medullary thyroid carcinoma at autopsy. Journal of Clinical Endocrinology and Metabolism 96 E109-E113. (https://doi.org/10.1210/jc.2010-0959)

Verrienti A, Tallini G, Colato C, Boichard A, Checquolo S, Pecce V, Sponziello M, Rosignolo F, de Biase D, Rhoden K, et al. 2016 RET mutation and increased angiogenesis in medullary thyroid carcinomas. Endocrine-Related Cancer 23 665-676. (https://doi. org/10.1530/ERC-16-0132)

Viola D, Valerio L, Molinaro E, Agate L, Bottici V, Biagini A, Lorusso L, Cappagli V, Pieruzzi L, Giani C, et al. 2016 Treatment of advanced thyroid cancer with targeted therapies: ten years of experience. Endocrine-Related Cancer 23 R185-R205. (https://doi.org/10.1530/ ERC-15-0555)

Vojtek AB \& Der CJ 1998 Increasing complexity of the Ras signaling pathway. Journal of Biological Chemistry 273 19925-19928. (https:// doi.org/10.1074/jbc.273.32.19925)

Vuong HG, Odate T, Ngo HTT, Pham TQ, Tran TTK, Mochizuki K, Nakazawa T, Katoh R \& Kondo T 2018 Clinical significance of RET and RAS mutations in sporadic medullary thyroid carcinoma: a meta-analysis. Endocrine-Related Cancer 25 633-641. (https://doi. org/10.1530/ERC-18-0056)

Wedge SR, Ogilvie DJ, Dukes M, Kendrew J, Chester R, Jackson JA, Boffey SJ, Valentine PJ, Curwen JO, Musgrove HL, et al. 2002 ZD6474 inhibits vascular endothelial growth factor signaling, angiogenesis, and tumor growth following oral administration. Cancer Research 62 4645-4655.

Wells Jr SA 2018 Advances in the management of MEN2: from improved surgical and medical treatment to novel kinase inhibitors. Endocrine-Related Cancer 25 T1-T13. (https://doi. org/10.1530/ERC-17-0325)

Wells Jr SA, Robinson BG, Gagel RF, Dralle H, Fagin JA, Santoro M, Baudin E, Elisei R, Jarzab B, Vasselli JR, et al. 2012 Vandetanib in patients with locally advanced or metastatic medullary thyroid cancer: a randomized, double-blind phase III trial. Journal of Clinical Oncology 30 134-141. (https://doi.org/10.1200/ JCO.2011.35.5040)

Wells Jr SA, Asa SL, Dralle H, Elisei R, Evans DB, Gagel RF, Lee N, Machens A, Moley JF, Pacini F, et al. 2015 Revised American Thyroid Association guidelines for the management of medullary thyroid carcinoma. Thyroid 25 567-610. (https://doi.org/10.1089/ thy.2014.0335)

Wullschleger S, Loewith R \& Hall MN 2006 TOR signaling in growth and metabolism. Cell 124 471-484. (https://doi.org/10.1016/j. cell.2006.01.016)

Zatelli MC, Piccin D, Tagliati F, Bottoni A, Luchin A, Vignali C, Margutti A, Bondanelli M, Pansini GC, Pelizzo MR, et al. 2006 Selective activation of somatostatin receptor subtypes differentially modulates secretion and viability in human medullary thyroid carcinoma primary cultures: potential clinical perspectives. Journal of Clinical Endocrinology and Metabolism 91 2218-2224. (https://doi. org/10.1210/jc.2006-0334)

Received in final form 17 June 2019

Accepted 26 June 2019

Accepted Preprint published online 26 June 2019
C) 2019 Society for Endocrinology Published by Bioscientifica Ltd. Printed in Great Britain 